Original Article

\title{
BIOAVAILABILITY STUDY OF ONDANSETRON GEL IN RABBITS AND HUMAN VOLUNTEERS APPLING UPLC AS ANALYTICAL TOOL AND EVALUATION OF THE ANTIEMETIC EFFECT OF ONDANSETRON GEL IN CISPLATIN-INDUCED EMESIS IN RATS
}

\author{
MONA M. EL-MAHDY ${ }^{1}$, MAI M. RASHEEDY ${ }^{1}$, ELSAYED A. IBRAHIM ${ }^{1}$, DINA FATHALLAH ${ }^{1 *}$ \\ 1Department of Pharmaceutics, Faculty of Pharmacy, Assiut University, Assiut 71526, Egypt \\ Email: dinafathalla3@gmail.com
}

Received: 19 Dec 2019, Revised and Accepted: 04 Feb 2020

\section{ABSTRACT}

Objective: This study was undertaken to determine the bioavailability of ondansetron gel in experimental animals and humans applying UPLC as an analytical tool and evaluation of the antiemetic effect of ondansetron gel in cisplatin-induced emesis in rats.

Methods: Ondansetron gel (F13: sodium alginate $7 \% \mathrm{w} / \mathrm{w}$ ) was used, marketed I. V. ondansetron (Zofran) ${ }^{\circledR}$ was chosen as reference. The bioavailability study in rabbits was selected as a parallel design using nine healthy rabbits divided into three groups whereas, bioavailability study in humans was an open-label, wherein 6 healthy subjects administered ondansetron gel. The potential effect of ondansetron gel was evaluated for the prevention of different phases of emesis motivated by exposure to antineoplastic drugs (cisplatin) by determination of body weight loss, water and food intake applying kaolin-pica model in rats using seventy-two rats divided into six groups.

Results: Ondansetron gel (0.5\%) showed detectable plasma concentration $22.833 \pm 2.17 \mathrm{ng} / \mathrm{m} 1 \mathrm{after} 1 / 4 \mathrm{~h}$ and $419.55 \pm 2.17 \mathrm{ng} / \mathrm{ml}$ after 1 - $\mathrm{h}$ posttreatment in rabbits and human respectively and concentration was maintained above-reported minimum effective concentration for more than 2.5 $\mathrm{h}$ for rabbits and $7 \mathrm{~h}$ for humans compared to $1.75 \mathrm{~h}$ after I. V. administration.

The ondansetron gel significantly reduces all phases of cisplatin-induced emesis and a decrease in body weight, water, and food consumption was significantly attenuated.

Conclusion: Based on the high efficacy of gel on emesis induced by cisplatin, and its high bioavailability, transdermal ondansetron gel could be a promising convenient system to prevent nausea and vomiting following administration of antineoplastic drugs.

Keywords: Ondansetron, Transdermal gel, Bioavailability, UPLC, Cisplatin-induced emesis in rats

(C) 2020 The Authors. Published by Innovare Academic Sciences Pvt Ltd. This is an open-access article under the CC BY license (http://creativecommons.org/licenses/by/4.0/) DOI: http://dx.doi.org/10.22159/ijpps.2020v12i3.36667. Journal homepage: https://innovareacademics.in/journals/index.php/ijpps

\section{INTRODUCTION}

Ondansetron is a selective 5 - $\mathrm{HT}_{3}$ (5-hydroxytryptamine, or serotonin) antagonist receptor [1-5]. It is a primary drug utilized to treat, prohibit and stop chemotherapy-induced nausea and vomiting (CINV), it is also efficient in prevailing postoperative nausea and vomiting (PONV) and after radiation therapy-induced nausea and vomiting [6-8]. Ondansetron is taken 1-3 times daily, and it is available commercially as an oral and disintegrable tablet, solution, and injection [8]. Intravenous (IV) route has quick effects, but it confers a local pain and for its short half-life, ondansetron requires recurrent administrations. Also, oral administration has many disadvantages as it not desirable in nausea and vomiting, difficulties occurred in the gastrointestinal tract during absorption due to enzymes, food-drug interactions, etc. [8]. Subsequently, it is very eligible to develop another delivery system to overcome the side effects associated with IV and/or oral dosage forms. So, ondansetron transdermal gel was formulated and evaluated from previous in vitro and ex vivo studies [9]. Whereas it is especially suitable for cancer patients who suffer from frequent episodes of vomiting and nausea and thus they cannot keep the oral dosage form and intravenous chemotherapy formerly worn out their veins.

Pharmacokinetic and biopharmaceutical studies of drug products are useful tools to investigate the relationship between physicochemical properties of the drug and the pharmacological effect produced [10]. Measurement of drug concentration in biological fluids, such as blood or urine following drug administration is considered a direct and efficient method for the determination of systemic drug bioavailability [11]. However, quantitative measurement of drug concentration in biological fluids is not always available or, in other instances, lacks sufficient accuracy. In this case, the pharmacological effect of the drug can be used as an indirect measure of drug bioavailability [12].
Nausea and vomiting associated with the administration of chemotherapeutic drugs are attributed to the activation of serotonin type 3 receptors existing in the gastrointestinal tracts and/or central nervous system [13-16] due to cellular damage to the intestinal mucosa [17]. Cisplatin, a common chemotherapy drug, has many hurtful side effects such as the stimulation of nausea, vomiting, anorexia and general malaise [18]. Cisplatin was classified as the highest emetic risk group as it causes acute and delayed vomiting $[19,20]$. So, selective $5-\mathrm{HT}_{3}$ receptor antagonists are very efficient in prohibiting nausea and emesis in animals [21, 22] and cancer patients [23, 24].

To evaluate the antiemetic efficacy, different animal models including ferrets, dogs, and monkeys have been utilized [25] However, generally, rodents such as mice and rats do not show vomiting behaviors, in comparison to the emesis-prone animals such as ferrets and dogs. Instead, mice and rats eat non-nutritive materials such as kaolin, so-called pica as a phenomenon of vomiting reflex, following treatment with poisons or under rotating situation [26-30]. It was proposed that increased pica is an illness-response behavior of the rat, similar to vomiting in other species and humans [26], which can be utilized as a readily-quantifiable behavioral assay of deleterious drug effects [27].

Thus, the main adjective of this study was to estimate a comparative bioavailability study of ondansetron gel formulation in rabbits and healthy human volunteers using intravenous ondansetron, as a reference standard applying UPLC as the analytical tool for assessing the drug concentration in plasma. Further, the investigation is extended to evaluate the potential effect of ondansetron from gel formulation for the prohibition of different phases of emesis encouraged by exposure to antineoplastic drugs such as cisplatin by determination of body weight loss, water and food intake employing a kaolin-ingesting pica model in rats. 


\section{MATERIALS AND METHODS}

\section{Materials}

Ondansetron was kindly provided by (Adwia Co., Cairo, Egypt), $\mathrm{K}_{3}$ EDTA ampoules (Voma med., Italy). Zofran ${ }^{\circledR}$ I. V. injection $8 \mathrm{mg} / 4$ $\mathrm{ml}$ (Glaxo Smithkline S. A. E. El-Salam City, Egypt). HPLC grade of Acetonitrile and methanol (Sigma Chemical Co. St. Louis, Mo, USA). Cisplatine ${ }^{\circledR}$, I. V. vial $10 \mathrm{mg} / 10 \mathrm{ml}$ (Mylan, France). Sodium alginate (The General Chemical and Pharmaceutical Co., Ltd., England). Standard rat chow pellets. Kaolin of pharmaceutical grade (Clay, naturally hydrated aluminum silicate) was purchased from (ELGomhouria Co., Egypt). Acacia (gum Arabic) (ISO-CHEM, Egypt). All chemicals and reagents used were of analytical grade.

\section{Methods}

\section{Preparation of ondansetron gel (F13)}

The gel was prepared by dissolving an accurately weighed 0.5 gram of ondansetron powder in a mixture of 5 grams polyethylene glycol 400 and 1.5 grams polyvinyl pyrrolidone and $50 \mathrm{ml}$ of distilled water using a magnetic stirrer. The remaining amount of distilled water required to prepare $100 \mathrm{~g}$ of the gel was added to the specified amounts of the gelling polymer sodium alginate $(7 \% \mathrm{w} / \mathrm{w})$ and soaked overnight for complete polymer solvation. The drug mixture was added slowly to the previously soaked polymer and continuously stirred to get the required gels using magnetic stirrer [9].

Transdermal bioavailability study of ondansetron gel in experimental animals (rabbits) and human volunteers applying UPLC as the analytical tool

\section{Experimental design}

\section{a. Bioavailability studies in rabbits}

Ondansetron sodium alginate gel $(7 \% \mathrm{w} / \mathrm{w})$ (F13) was selected for this study which showed a greater extent of permeation than other gels [9]. Marketed I. V. ondansetron (Zofran) ${ }^{\circledR}$ was chosen as the reference standard.

A parallel design study was selected using nine healthy New Zealand rabbits weighing 1.75-2 kg (Animal house of faculty of Medicine, Assiut University-Egypt). Rabbits were fasted $12 \mathrm{~h}$ before the administration of the drug but had free access to water [31] and were housed at room temperature. Food was not allowed after drug administration [32]. The study protocol was approved and carried out according to the animal ethics guidelines of the Ethical Review Board of Faculty of Pharmacy, Assiut University Assiut, Egypt (No. S7-19).

Rabbits were divided randomly into three groups; each group consisted of three rabbits, and classified as:

1. The first group received marketed ondansetron injection Zofran ${ }^{\circledR}$ ( $8 \mathrm{mg} / 4 \mathrm{ml}$, Glaxo) for each rabbit using direct I. V. administration in the vein of an ear.

2. The second group received the gel formulation of a dose equal to 8 mg using $0.5 \%$ ondansetron gel).

3 . The third group received the gel formulation of a dose equal to 16 mg using $1 \%$ ondansetron gel).

The gel formulation was applied on an area of $4 \times 4 \mathrm{~cm}$ of rabbit's dorsal skin which shaved a day before the experiments. Blood samples were collected from the marginal ear vein at time intervals $0,0.25,0.5,0.75,1,1.5,2,2.5,3$ and $4 \mathrm{~h}$. The acclimation condition of animals was good before and after the experimental procedure.

\section{b. Bioavailability studies in healthy volunteers}

This study was designed to estimate the pharmacokinetic parameters of ondansetron gel formulation. The fundamental objective was to determine the bioavailability of ondansetron after a single application of the gel $(8 \mathrm{mg}$ using $0.5 \%$ ondansetron gel and $16 \mathrm{mg}$ using $1 \%$ ondansetron gel) behind the ear for $7 \mathrm{~h}$. Secondary objectives included determination of local tolerance, safety, and tolerability of the gel. An open-label design study was selected, wherein 6 healthy subjects (3 males and 3 females) were administrated ondansetron gel. The study protocol was approved by the Research Ethics Committee at the Faculty of Medicine, Assiut University Assiut, Egypt No. 17300082.

The volunteers were in good health as determined by a physician, with a weight of more than $50 \mathrm{~kg}$ and a body mass index (BMI) of $26-31 \mathrm{~kg} / \mathrm{m} 2$ and they were aged 21-36 y who were non-smoker for 3 mo. No medical history, physical examination, blood pressure and pulse rate findings at baseline were considered clinically relevant. All subjects were ready and eligible to participate in the study and provided written informed approval.

Exclusion criteria were: hypersensitivity to similar drugs or transdermal systems, taking any medication within $2 \mathrm{w}$ of study period, participation in another study within $30 \mathrm{~d}$ before receiving study medication, clinically significant symptoms in the 3 mo prestudy, probably need treatment during the study period, presence of situations known to intervene with any drug pharmacokinetics, any skin conditions at site of application that may block evaluations, a history of headaches or subject unlikely to comply with protocol like uncooperative attitude [33,34].

Volunteers were instructed not to take any other medication through the study period. Also, they were advised to avert taking baths, exposure to sun or use any cream or oil at application sites of the gel [34].

\section{Blood sampling}

Serial blood samples of (1-2 $\mathrm{ml})$ were withdrawn before gel application and at several time intervals, into a 5-ml screw-capped centrifuge tube with $\mathrm{K}_{3}$ EDTA as anticoagulant [35]. Drug-free blood samples were taken from each group before the initiation of the treatment. Samples were centrifuged (using Bench-top centrifuge, model 3-30K, Sigma, Germany) at $4500 \mathrm{rpm}$ at $4{ }^{\circ} \mathrm{C}$ for $15 \mathrm{~min}$ [36]. The clear supernatant (separated plasma) was taken away and transferred into a new screw-capped centrifuge tube and stored at $-20^{\circ} \mathrm{C}$ until being analyzed $[36,37]$.

\section{Extraction and analysis of blood samples}

The extraction of ondansetron from plasma samples was carried out. First, to precipitate proteins a $200 \mu \mathrm{l}$ of acetonitrile were added to $200 \mu \mathrm{l}$ of plasma, then the mixture was vortexed (Vortex Mixer, model Fine Vortex, Fine PCR ${ }^{\circledR}$, Korea) for 2 min and centrifuged at $10,000 \mathrm{rpm}$ at $4{ }^{\circ} \mathrm{C}$ for $20 \mathrm{~min}$ and $5 \mu \mathrm{l}$ of supernatant was filtered then injected directly into the UPLC apparatus (Acquity ${ }^{\mathrm{TM}}$ UPLC, Model CHA, Serial \# B 15CHA 4326, C18 column of $1.7 \mu$ m particle size and $2.1 \times 100 \mathrm{~mm}$ inner diameter, PDA-e $\lambda$ Detector, Empower- 2 software, Singapore) with Ultraviolet spectrophotometer (Jenway 6305 Single Beam spectrophotometer, U. K)for analysis [1]. The UPLC analysis was performed on a reversed-phase UPLC system using a mobile phase of methanol $(70 \% \mathrm{v} / \mathrm{v})$ containing ultrapurified distilled water, with a $0.24 \mathrm{ml} / \mathrm{min}$ flow rate at $304 \mathrm{~nm}$ using UV detector [38, 27, 39].

\section{Calibration curve of ondansetron in plasma}

The standard calibration curve of ondansetron in plasma was constructed utilizing drug-seven plasma spiked with standard ondansetron solutions to get a concentration range from 20-1000 $\mathrm{ng} / \mathrm{ml}$. The spiked plasma was then undergoing the same extraction procedure as the samples. Triplicate running was done for each standard sample to assess the reproducibility of the detector at each concentration. Unknown concentrations of ondansetron were calculated from this calibration curve which was obtained by plotting various known ondansetron concentrations versus the corresponding peak areas.

\section{Recovery of ondansetron from plasma samples}

Recovery of ondansetron from plasma samples was determined by replicate analysis of plasma samples containing known amounts of the drug. As in the standard preparation, the samples were spiked to the blood and it was extracted, collected in vials and injected into the UPLC system. The amount of the drug to be added was calculated as well as the amount found was calculated [39]. 


\section{Pharmacokinetic analysis of data}

After measuring the ondansetron concentration in plasma, the pharmacokinetic parameters were investigated by analyzing the plasma concentration-time data according to the method of residuals. The maximum plasma concentration $\left(\mathrm{C}_{\max }\right)$ and time to reach $\mathrm{C}_{\max }\left(\mathrm{T}_{\max }\right)$ were gained directly from the data. Absorption rate constant $\left(\mathrm{K}_{\mathrm{a}}\right)$, absorption half-life $\left(\mathrm{t}_{1 / 2 \mathrm{a}}\right)$, elimination rate constant $\left(\mathrm{K}_{\mathrm{el}}\right)$, elimination half-life $\left(\mathrm{t}_{1 / 2}\right)$ and area under the ondansetron plasma concentration versus time curve (AUC) were computed according to conventional algorithms using the log plasma concentration $v$ s. time curve [40]. The elimination half-life $\left(\mathrm{t}_{1 / 2}\right)$ was computed by dividing 0.693 with $\mathrm{K}_{\mathrm{el}}[40]$.

\section{Common adverse effects assessment}

Adverse effects were observed by the inspectors (local or systemic) as well as volunteers were asked to record any things that happened during the study.

\section{Local dermal tolerance evaluation}

Local tolerance was estimated by the inspectors employing a scoring system, clinical examination, and registering the appearance of adverse effects. The irritation scoring system was as follows: $0=$ no evidence of irritation, $1=$ minimal erythema, hardly sensible, $2=$ specified erythema, easily visible, minimum edema, or minimal papular reaction, $3=$ erythema and papules, $4=$ specified edema, $5=$ erythema, edema, and papules, $6=$ vesicular eruption and $7=$ powerful reaction at site of application.

Also, volunteer was asked about the potential manifestation of pruritus and burning/stinging feelings, and if recorded, the intensity of this reaction was classified from 0 to 3 as follows: $0=$ none, $1=$ mild: some feelings of pruritus/burning, intermittent, without consequence on daily activity, 2 = moderate: moderate feelings of pruritus/burning, persistent, with some intervention with daily activity and 3 = severe: strong pruritus/burning feelings, persistent, interfering with daily activity, and/or demanding gel elimination, and/or impairing sleep [33].

Study of the antiemetic effect of ondansetron gel in cisplatininduced emesis in rats

\section{Experimental animals}

Seventy-two female Albino Wister rats, weighing 160-190 gm (Animal house of faculty of Medicine, Assiut University-Egypt), adopted to the laboratory environments for $3 \mathrm{~d}$ before experiments. They were kept under normal conditions of an appropriate humidity and temperature and $12 \mathrm{~h}$ of light/dark cycle.

All rats were pliable to free access to kaolin, standard rat chow pellets, and water. The standard rat chow and kaolin pellets were put in separate containers during the experiment to prohibit their blending and to enable the more precise calculation of weight. All the experiments were done according to animal ethics guidelines of the Ethical Review Board of Faculty of Pharmacy, Assiut University Assiut, Egypt (No. S7-19).

Kaolin pellets were formulated according to the procedure of Mitchell $e t$ al. (1976) [41]. First, $50 \mathrm{~g}$ of pharmaceutical-grade kaolin was added and mixed with $1 \mathrm{~g}$ of acacia at ratio 50:1 with distilled water to form a dense paste. Then, the paste was extruded through a syringe onto wire mesh trays to dry at room temperature. After partial drying, pellets of kaolin mixture were shaped to resemble the size and volume of the normal laboratory diet. The kaolin pellets were set on plastics trays and dried at room temperature for up to $48 \mathrm{~h}[42,43]$.

\section{Procedures}

Rats were divided randomly into six groups (each group consists of twelve rats) and classified as follows: 1 = control group, $2=$ Blank group with ondansetron gel, 3 = Cisplatin group with a dose of $10 \mathrm{mg} / \mathrm{kg}$, intraperitoneal (I. P.) daily injection (acute phase), 4 = Cisplatin group with a dose of $10 \mathrm{mg} / \mathrm{kg}$ I. P. daily injection (acute phase) and $0.5 \%$ ondansetron gel twice daily, $5=$ Cisplatin group with a dose of $5 \mathrm{mg} / \mathrm{kg}$, I. P. injection every $3 \mathrm{~d}$ (acute and delayed phase), and $6=$ Cisplatin group with a dose of $5 \mathrm{mg} / \mathrm{kg}$ I. P. injection every $3 \mathrm{~d}$ (acute and delayed phase) and $0.5 \%$ ondansetron gel twice daily.
The rats were given individually cisplatin intraperitoneal. The dosage of cisplatin was selected to induce dose-limiting emesis (acute and delayed) as $10 \mathrm{mg} / \mathrm{kg}$ dose to encourage acute emesis, which peaked after $2 \mathrm{~h}$, while $5 \mathrm{mg} / \mathrm{kg}$ dose induced a biphasic profile of emesis; the acute phase began $10 \mathrm{~h}$ after cisplatin administration, peaked after $12 \mathrm{~h}$ and a nadir was attained after 24 $\mathrm{h}$. The delayed stage was more strong and prolonged than the acute phase and attained a peak $48 \mathrm{~h}$ post cisplatin before gradually decreasing in severity during the next $24 \mathrm{~h}$ until $72 \mathrm{~h}$ post cisplatin, at which time a small amount of emesis continued [20,44].

One gram of ondansetron gel $0.5 \%$ was dermally applied on an area of $2 \times 3 \mathrm{~cm}$ of rat dorsal skin which shaved in the adaptation days before the experiment to animals $12 \mathrm{~h}$ before exposure to cisplatin and repeated every $12 \mathrm{~h}$. Rats were returned to cages for the estimation of daily kaolin, water, and feed intake and body weight changes during the next experiment time.

Kaolin, normal feed and water containers were removed each day at the same time and any spillage of them was collected and weighed using Digital balance (Precisa, Switzerland) to the nearest $0.01 \mathrm{~g}$, food hoppers were then refilled and weighed. The volume of the bottle of water was also determined and refilled by fresh tap water. The quantity consumed within every $24 \mathrm{~h}$ was evaluated by matching the weights with the former weights. The following equation was applied to determine the ultimate weight value:

Ultimate weight value (day n) = weight (day n)-weight (day n+1) [45].

\section{Statistical analysis}

The differences between experimental groups were analyzed by using one-way analysis of variance (ANOVA) and Tukey-Test as a post-hoc test or two-way ANOVA followed by post hoc Bonferroni multiple comparison test. A probability of less than $0.05(\mathrm{p}<0.05)$ was considered statistically significant. Statistical analysis was executed employing Graph-Pad Prism (Graph Pad Prism 6.0, GraphPad, San Diego, CA).

\section{RESULTS AND DISCUSSION}

Transdermal bioavailability study of ondansetron gel in experimental animals (rabbits) and human volunteers applying UPLC as the analytical tool

Plasma samples were analyzed using ultra-performance liquid chromatography (UPLC) which is a rapid and sensitive method. This assay procedure could be useful for the pharmacokinetic study of ondansetron in humans and small animals such as rabbits [35,38].

UPLC is superior to high-performance liquid chromatography (HPLC) in achieving a very significant increase in resolution, speed, sensitivity and separation efficiency. UPLC gives faster results with better resolution, uses less valuable solvents which lower cost and is more environmentally friendly than HPLC.

\section{Calibration curve of ondansetron in plasma}

The standard calibration curve of ondansetron in the rabbit's plasma is plotted in (fig. 1a) A straight line was obtained with an excellent correlation coefficient $(\mathrm{R} 2=0.9998)$, which re flects good linearity of the relationship over the investigated concentration range $(50-1000 \mathrm{ng} / \mathrm{ml})$. The retention times obtained for ondansetron in the mobile phase and rabbit plasma was around 0.93 and $1.312 \mathrm{~min}$, respectively comparing to 8-9 min of reported retention time [39]. These chromatography conditions con firm the accuracy and reliability of this assay method to serve as a practical tool for the analysis of ondansetron in plasma samples. $(\mathrm{R} 2=0.9998$, slope $=42.313$, intercept $=-0.659)$

The standard calibration curve of ondansetron in human plasma is plotted in (fig. 1b) A straight line was obtained with an excellent correlation coefficient $\left(R^{2}=0.9993\right)$, which reflects good linearity of the relationship over the investigated concentration range $20-800$ $\mathrm{ng} / \mathrm{ml}$ ). The retention times obtained for ondansetron in human plasma were around $1.55 \mathrm{~min}$.

\section{Recovery from plasma samples}

The chromatograms show sharp and identifiable peaks. Moreover, the ondansetron peaks showed high resolution without interference 
with the endogenous plasma components. The average recovery of ondansetron from spiked plasma samples ranged from 99.4 to 100.7 $\%$, which reflects good efficiency of the extraction procedure as shown in (fig. 2.)

\section{Bioavailability studies in rabbits}

Based on previous results obtained from ex vivo permeation studies, the suitable formulation that selected was ondansetron gel (F13:
$7 \% \mathrm{w} / \mathrm{w}$ sodium alginate) [9]. In this study, the selected formula with different concentrations exhibited a slower, but higher extent of permeation in four hours than the I. V. application. During the study, it was observed that no remarkable signs of any irritation or redness at application sites.

The UPLC method used for the determination of the concentrations of ondansetron permeated from skin to the systemic circulation was sufficiently precise and convenient for the analysis.

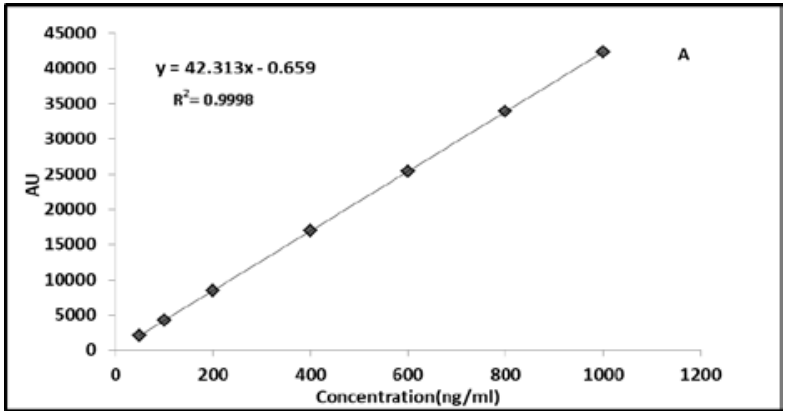

A-rabbit's plasma

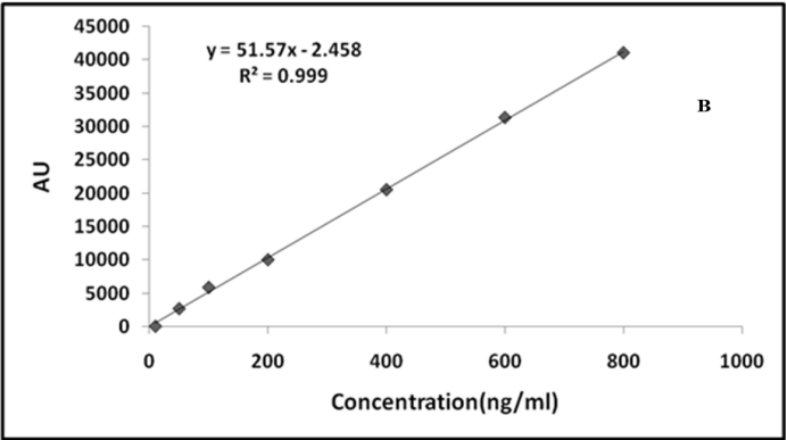

B-human`s plasma

Fig. 1: UPLC calibration curve of ondansetron in (a) rabbit's plasma and (b) human`s plasma
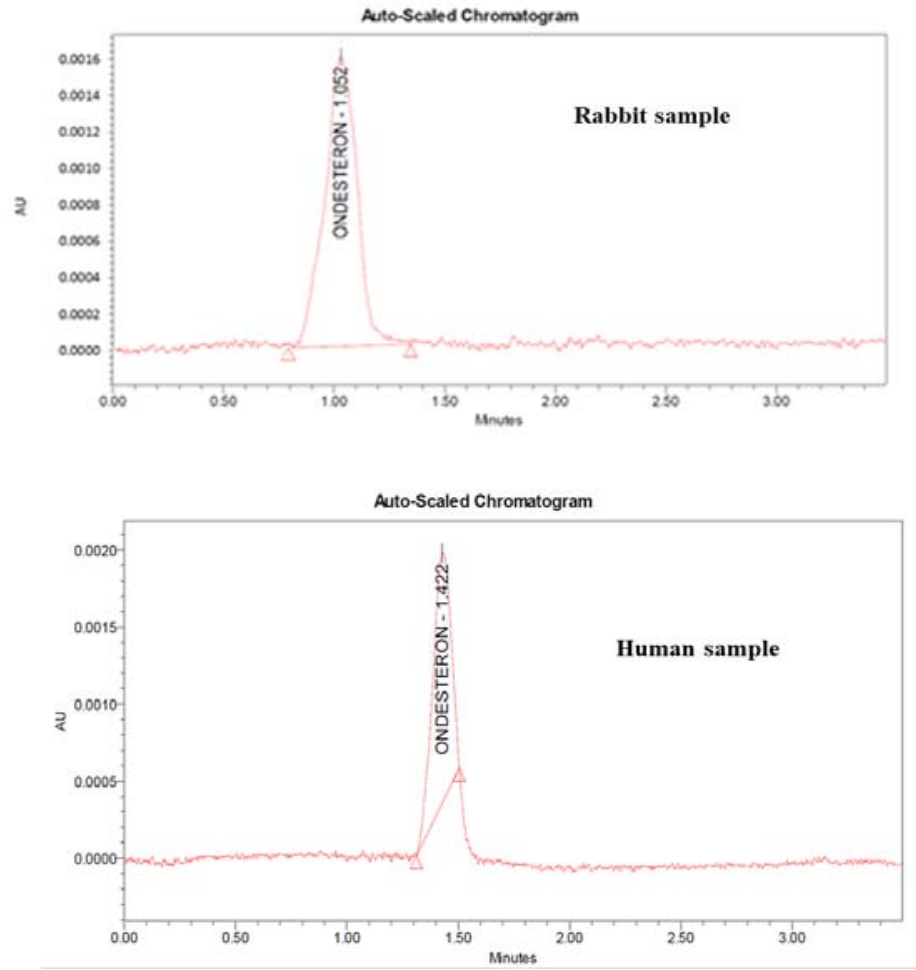

Fig. 2: UPLC chromatograms of blank plasma (rabbits and human) spiked with ondansetron at concentration $400 \mathrm{ng} / \mathrm{ml}$ 
From the calibration curve, the plasma drug concentrations were determined for each rabbit and the mean plasma drug concentrations were calculated, with a standard deviation for each treatment group, and the drug concentration-time profiles were plotted. The mean plasma concentration-time profiles of ondansetron following gel application of the selected formulation with different concentrations and IV injection of ondansetron was shown in (fig. 3a, b). It could be seen that; the transdermal ondansetron $(0.5 \%)$ gel formula showed plasma detectable concentration of $(22.833 \pm 2.17 \mathrm{ng} / \mathrm{m} 1)$ after $1 / 4 \mathrm{~h}$ post-treatment and the concentration was maintained nearer the reported minimum effective concentration (MEC) of ondansetron that it is 30 $\mathrm{ng} / \mathrm{ml}$ [46] for more than $2.5 \mathrm{~h}$. While the transdermal ondansetron (1\%) gel formula showed a plasma detectable concentration of $(212 \pm 38.432 \mathrm{ng} / \mathrm{ml})$ after $1 / 4 \mathrm{~h}$ post-treatment and the concentration still detectable for $4 \mathrm{~h}$.

The plasma drug concentration of transdermal gel formula which contains $0.5 \%$ ondansetron increased progressively to reach maximum concentration $\mathrm{C}_{\max }$ of $(116.669 \pm 14.418 \mathrm{ng} / \mathrm{m} 1)$ at $\mathrm{T}_{\max }$ of $(1.5 \mathrm{~h})$, then decreasing to $(13.667 \pm 2.082 \mathrm{ng} / \mathrm{m} 1)$ at $4 \mathrm{~h}$ after transdermal administration. While, the plasma drug concentration of transdermal gel formula which contains 1\% ondansetron increased progressively to reach maximum concentration $C_{\max }$ of $(373 \pm 43.92$ $\mathrm{ng} / \mathrm{m} 1)$ at $\mathrm{T}_{\max }$ of $(1.5 \mathrm{~h})$, and then decreasing to $(26.33 \pm 5.508$ $\mathrm{ng} / \mathrm{m} 1$ ) at $4 \mathrm{~h}$ after transdermal administration.

The plasma profile of ondansetron after I. V. administration in the rabbits shows the $C_{\max }: 311.037 \pm 20.518 \mathrm{ng} / \mathrm{ml}$ just after injection. The plasma concentration decreased to reach $(15.743 \pm 5.444 \mathrm{ng} / \mathrm{ml})$ at $2 \mathrm{~h}$ after injection. The pharmacokinetic parameters of ondansetron were assessed and listed in tables 1-3.

\section{Bioavailability studies in healthy volunteers}

Using the calibration curve, the plasma drug concentrations were determined for each volunteer and the mean plasma drug concentrations were calculated, with a standard deviation for each treatment group, and the drug concentration-time profiles were plotted. The plasma drug concentrations of ondansetron were represented in (fig. 4) It could be seen that; the transdermal gel containing $0.5 \%$ ondansetron showed a plasma detectable concentration of $(419.55 \pm 2.17 \mathrm{ng} / \mathrm{ml})$ after 1 -h post-treatment and the concentration was maintained above the reported minimum effective concentration (MEC) for ondansetron that it is $30 \mathrm{ng} / \mathrm{ml} \mathrm{[46]} \mathrm{for} \mathrm{more} \mathrm{than} 7 \mathrm{~h}$.

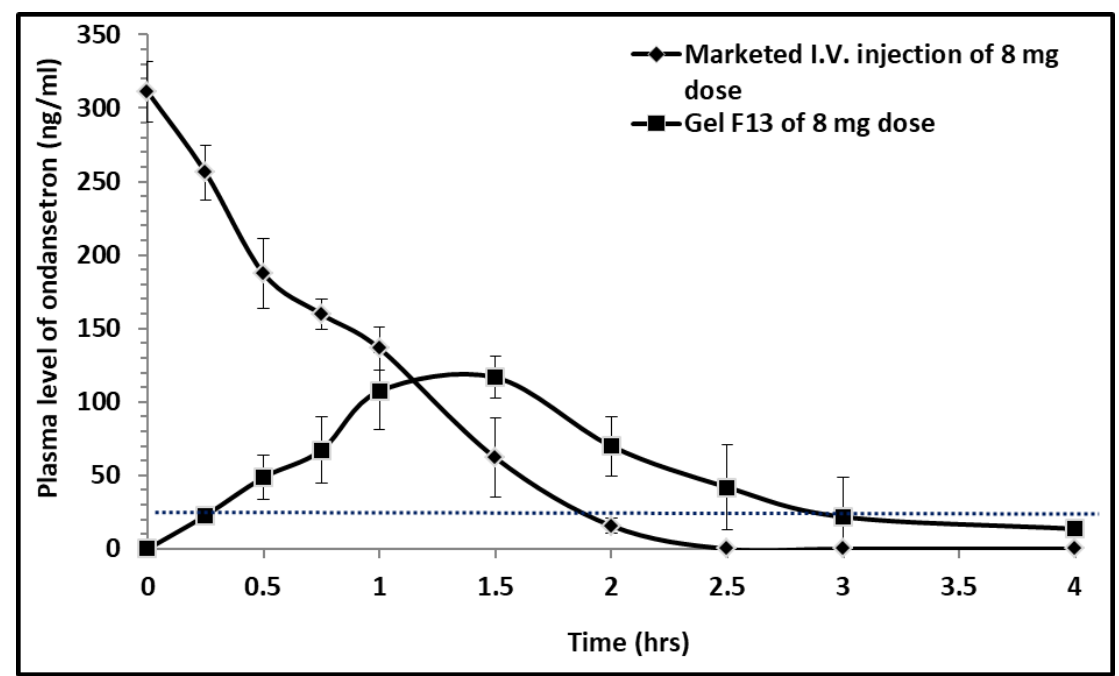

a- Gel F13 of $8 \mathrm{mg}$ dose

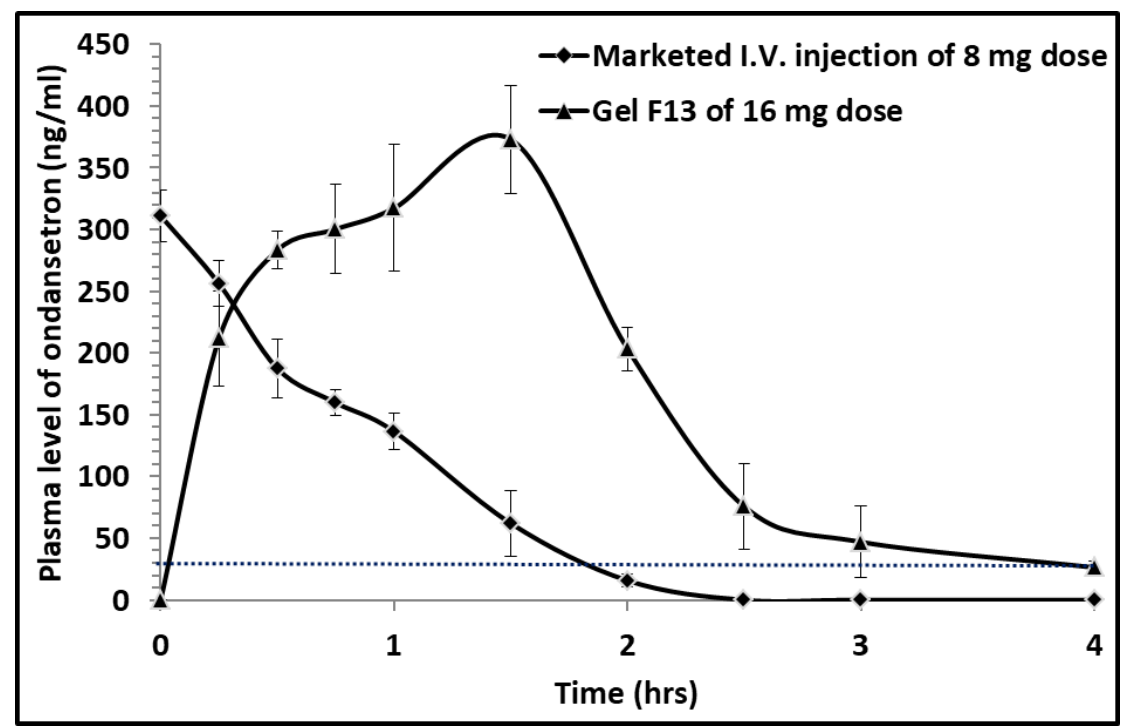

b- Gel F13 of $16 \mathrm{mg}$ dose

Fig. 3: Mean plasma concentration-time profile of ondansetron after administration of gel formula (F13) of (a) $8 \mathrm{mg} \mathrm{dose} \mathrm{(b)} 16 \mathrm{mg} \mathrm{dose}$ as compared to the marketed I. V. injection 


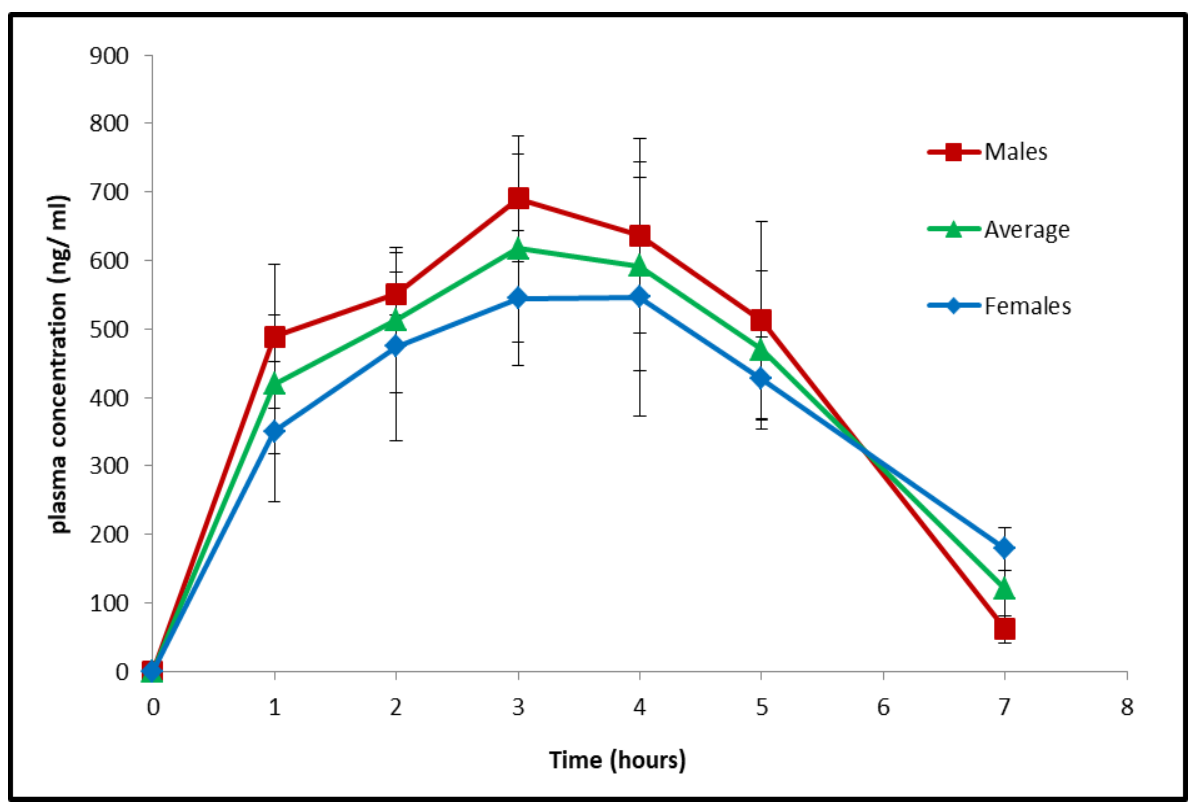

Fig. 4: Mean plasma concentration-time profiles following administration of ondansetron gel F13 $0.5 \%$ (8 $\mathrm{mg}$ ) in males and females

Table 1: Pharmacokinetics parameters ${ }^{(a)}$ of ondansetron I. V. administration of Zofran ${ }^{\circledR}$ and the gel formula F 13 to rabbits (8 mg/dose)

\begin{tabular}{|c|c|c|c|c|}
\hline $\begin{array}{l}\text { Pharmacokinetics } \\
\text { parameter (a) }\end{array}$ & $\begin{array}{l}\text { Marketed I. V. ondansetron } \\
(8 \mathrm{mg} / \text { dose })\end{array}$ & $\begin{array}{l}\text { Transdermal gel F13 } \\
(8 \mathrm{mg} / \text { dose })\end{array}$ & P value & Significance of the difference ${ }^{(c)}$ \\
\hline $\mathrm{C}_{\max }(\mathrm{ng} / \mathrm{ml})$ & $311.037 \pm 20.518$ & $117.168 \pm 4.603$ & 0.001 & **** \\
\hline $\mathrm{T}_{\max }(\mathrm{h})$ & 0 & 1.5 & 0.001 & *** \\
\hline $\mathrm{K}_{\mathrm{a}}\left(\mathrm{h}^{-1}\right)$ & ---- & $1.844 \pm 0.019$ & ---- & ---- \\
\hline$t_{1 / 2 a}(h)$ & ---- & $0.376 \pm 0.004$ & ---- & ---- \\
\hline $\mathrm{K}_{\mathrm{el}}\left(\mathrm{h}^{-1}\right)$ & $1.255 \pm 0.079$ & $1.176 \pm 0.221$ & 0.05 & NS \\
\hline$t_{1 / 2 \mathrm{el}}(\mathrm{h})$ & $0.553 \pm 0.035$ & $0.605 \pm 0.152$ & 0.05 & NS \\
\hline AUC ${ }_{0-\infty}(\mu \mathrm{g} . \mathrm{h} / \mathrm{ml})$ & $0.303 \pm 0.039$ & $0.22 \pm 0.022$ & 0.05 & NS \\
\hline $\operatorname{AUMC}_{0-\infty}\left(\mu \mathrm{g} \cdot \mathrm{h}^{2} / \mathrm{ml}\right)$ & $0.249 \pm 0.048$ & $0.413 \pm 0.099$ & 0.05 & NS \\
\hline $\mathrm{MRT}_{0-\infty}(\mathrm{h})$ & $0.816 \pm 0.055$ & $1.78 \pm 0.152$ & 0.001 & $* * *$ \\
\hline $\mathrm{Cl}_{\mathrm{T}}(\mathrm{L} / \mathrm{h})$ & $26.686 \pm 3.303$ & $36.529 \pm 3.615$ & $<0.05$ & * \\
\hline $\mathrm{V}_{\mathrm{d}}$ (liter) & $21.217 \pm 1.409$ & $31.725 \pm 3.83$ & $<0.01$ & $* *$ \\
\hline $\mathrm{F}(\%)$ & 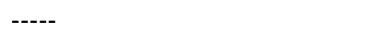 & $73.01 \pm 5.124$ & & ---- \\
\hline
\end{tabular}

${ }^{a}$ mean $\pm S D(n=3),{ }^{b} C_{\max }$ : maximum plasma concentration, $T_{\max }$ : time to reach $\mathrm{C}_{\max }, \mathrm{K}_{\mathrm{a}}$ : absorption rate constant, $\mathrm{t}_{1 / 2 \mathrm{a}}$ : absorption half-life, $\mathrm{K}_{\mathrm{el}}$ : elimination rate constant, $\mathrm{t}_{1 / 2}$ : elimination half-life, AUC: area under the ondansetron plasma concentration versus time curve, AUMC: area under the moment vs. time curve, MRT: mean residence time, Cl: clearance, $\mathrm{V}_{\mathrm{d}}$ : volume of distribution, F: fraction absorbed (bioavailability). chighly significant ${ }^{* * *}$ p 0.001 , moderate significant ${ }^{* *}$ p 0.01 , mild significant $*$ p 0.05 , non-significant NS p $>0.05$

Table 2: Pharmacokinetics parameters (a) of ondansetron I. V. administration of Zofran ${ }^{\circledR}$ and the gel formula F13 to rabbits (16 mg/dose)

\begin{tabular}{|c|c|c|c|c|}
\hline $\begin{array}{l}\text { Pharmacokinetics } \\
\text { parameter (a) }\end{array}$ & $\begin{array}{l}\text { Marketed I. V. ondansetron } \\
(8 \mathrm{mg} / \text { dose) }\end{array}$ & $\begin{array}{l}\text { Transdermal gel F13 } \\
(16 \mathrm{mg} / \text { dose })\end{array}$ & P-value & Significance of the difference ${ }^{(c}$ \\
\hline $\mathrm{C}_{\max }(\mathrm{ng} / \mathrm{ml})$ & $311.037 \pm 20.518$ & $360.833 \pm 24.168$ & $<0.05$ & * \\
\hline $\mathrm{T}_{\text {max }}(\mathrm{h})$ & 0 & 1.5 & 0.001 & $* * *$ \\
\hline $\mathrm{K}_{\mathrm{a}}\left(\mathrm{h}^{-1}\right)$ & ----- & $2.022 \pm 0.049$ & ---- & ---- \\
\hline $\mathrm{t}_{1 / 2 \mathrm{a}}(\mathrm{h})$ & ----- & $0.343 \pm 0.008$ & -.-- & ---- \\
\hline $\mathrm{K}_{\text {el }}\left(\mathrm{h}^{-1}\right)$ & $1.255 \pm 0.079$ & $1.065 \pm 0.068$ & 0.05 & * \\
\hline $\mathrm{t}_{1 / 2 \mathrm{el}}(\mathrm{h})$ & $0.553 \pm 0.035$ & $0.657 \pm 0.05$ & 0.05 & * \\
\hline $\operatorname{AUC}_{0-\infty}(\mu \mathrm{g} \cdot \mathrm{h} / \mathrm{ml})$ & $0.303 \pm 0.039$ & $0.721 \pm 0.044$ & 0.001 & $* * *$ \\
\hline $\operatorname{AUMC}_{0-\infty}\left(\mu \mathrm{g} . \mathrm{h}^{2} / \mathrm{ml}\right)$ & $0.249 \pm 0.048$ & $1.089 \pm 0.109$ & 0.001 & $* * *$ \\
\hline $\mathrm{MRT}_{0-\infty}(\mathrm{h})$ & $0.816 \pm 0.055$ & $1.503 \pm 0.051$ & 0.001 & $* * *$ \\
\hline $\mathrm{Cl}_{\mathrm{T}}(\mathrm{L} / \mathrm{h})$ & $26.686 \pm 3.303$ & $22.32 \pm 1.2$ & $>0.05$ & NS \\
\hline $\mathrm{V}_{\mathrm{d}}$ (liter) & $21.217 \pm 1.409$ & $20.989 \pm 0.286$ & $>0.05$ & NS \\
\hline $\mathrm{F}(\%)$ & ---- & $261.398 \pm 16.091$ & & -.-- \\
\hline
\end{tabular}

${ }^{\mathrm{a}}$ mean $\pm \mathrm{SD}(\mathrm{n}=3)$, ${ }^{\mathrm{b}} \mathrm{C}_{\max }$ : maximum plasma concentration, $\mathrm{T}_{\max }$ : time to reach $\mathrm{C}_{\max }, \mathrm{K}_{\mathrm{a}}$ : absorption rate constant, $\mathrm{t}_{1 / 2 \mathrm{a}}$ : absorption half-life, $\mathrm{K}_{\mathrm{el}}$ : elimination rate constant, $\mathrm{t}_{1 / 2}$ : elimination half-life, AUC: area under the ondansetron plasma concentration versus time curve, AUMC: area under the moment vs. time curve, MRT: mean residence time, Cl: clearance, $\mathrm{V}_{\mathrm{d}}$ : volume of distribution, F: fraction absorbed (bioavailability)chighly significant ${ }^{* * *}$ p 0.001 , moderate significant ${ }^{* *}$ p 0.01 , mild significant $*$ p 0.05 , non-significant NS $p>0.05$. 
Table 3: Pharmacokinetics parameters ${ }^{(a)}$ of ondansetron gel formula F13 with different doses (8 and $\left.16 \mathrm{mg}\right)$ to rabbits

\begin{tabular}{|c|c|c|c|c|}
\hline $\begin{array}{l}\text { Pharmacokinetics } \\
\text { parameter (a) }\end{array}$ & $\begin{array}{l}\text { Transdermal gel F } 13 \\
\text { (8 mg dose) }\end{array}$ & $\begin{array}{l}\text { Transdermal gel F } 13 \\
\text { (16 mg dose) }\end{array}$ & P value & Significance of the difference ${ }^{(c)}$ \\
\hline $\mathrm{C}_{\max }(\mathrm{ng} / \mathrm{ml})$ & $117.168 \pm 4.603$ & $360.83 \pm 24.17$ & 0.001 & $* * *$ \\
\hline $\mathrm{T}_{\max }(\mathrm{h})$ & 1.5 & 1.5 & $>0.05$ & Ns \\
\hline$K_{a}\left(h^{-1}\right)$ & $1.844 \pm 0.019$ & $2.022 \pm 0.049$ & $<0.01$ & $* *$ \\
\hline $\mathrm{t}_{1 / 2 \mathrm{a}}(\mathrm{h})$ & $0.376 \pm 0.004$ & $0.343 \pm 0.008$ & $<0.01$ & $* *$ \\
\hline $\mathrm{K}_{\mathrm{el}}\left(\mathrm{h}^{-1}\right)$ & $1.176 \pm 0.221$ & $1.065 \pm 0.068$ & $<0.05$ & $*$ \\
\hline $\mathrm{t}_{1 / 2 \mathrm{el}}(\mathrm{h})$ & $0.605 \pm 0.152$ & $0.657 \pm 0.05$ & $<0.05$ & * \\
\hline $\mathrm{AUC}_{0-\infty}(\mu \mathrm{g} . \mathrm{h} / \mathrm{ml})$ & $0.22 \pm 0.022$ & $0.721 \pm 0.044$ & 0.001 & $* * *$ \\
\hline $\operatorname{AUMC}_{0-\infty}\left(\mu \mathrm{g} . \mathrm{h}^{2} / \mathrm{ml}\right)$ & $0.413 \pm 0.099$ & $1.089 \pm 0.109$ & 0.001 & $* * *$ \\
\hline $\mathrm{MRT}_{0-\infty}(\mathrm{h})$ & $1.78 \pm 0.152$ & $1.503 \pm 0.051$ & $<0.05$ & * \\
\hline $\mathrm{Cl}_{\mathrm{T}}(\mathrm{L} / \mathrm{h})$ & $36.529 \pm 3.615$ & $22.32 \pm 1.2$ & $<0.01$ & $* *$ \\
\hline $\mathrm{V}_{\mathrm{d}}$ (liter) & $31.725 \pm 3.83$ & $20.989 \pm 0.29$ & $<0.01$ & $* *$ \\
\hline $\mathrm{F}(\%)$ & $73.01 \pm 5.124$ & $261.398 \pm 16.1$ & & ----- \\
\hline
\end{tabular}

${ }^{a}$ mean $\pm S D(n=3),{ }^{b} C_{\max }$ : maximum plasma concentration, $T_{\max }$ : time to reach $\mathrm{C}_{\max }, \mathrm{K}_{\mathrm{a}}$ : absorption rate constant, $\mathrm{t}_{1 / 2 \mathrm{a}}$ : absorption half-life, $\mathrm{K}_{\mathrm{el}}$ : elimination rate constant, $\mathrm{t}_{1 / 2}$ : elimination half-life, AUC: area under the ondansetron plasma concentration versus time curve, AUMC: area under the moment vs. time curve, MRT: mean residence time, $\mathrm{Cl}$ : clearance, $\mathrm{V}_{\mathrm{d}}$ : volume of distribution, $\mathrm{F}$ : fraction absorbed (bioavailability) chighly significant $^{* * *}$ p 0.001 , moderate significant ${ }^{* *}$ p 0.01 , mild significant $*$ p 0.05 , non-significant NS p $>0.05$

Each pharmacokinetic value was compared between men and women. Women consistently had significantly higher mean residence time (MRT) and elimination half time than men and the drug remained in higher value in women at $7 \mathrm{~h}$ post-application than men. While there is no significant differences were detected between genders in AUC for ondansetron gel.

Maximal plasma concentrations of ondansetron were attained after $3 \mathrm{~h}$. of application of an average of $617.22 \mathrm{ng} / \mathrm{ml}$. The plasma drug concentration of ondansetron $(0.5 \%)$ gel increased progressively to reach maximum concentration $\mathrm{C}_{\max }$ of $(690.27 \pm 57.75 \mathrm{ng} / \mathrm{m} 1)$ at $\mathrm{T}_{\max }$ of $(3 \mathrm{~h})$ for men and $\mathrm{C}_{\max }$ of $(546.92 \pm 70 \mathrm{ng} / \mathrm{m} 1)$ at $\mathrm{T}_{\max }$ of $(3.5$ h) for women, then decreasing to $(61.3 \pm 14 \mathrm{ng} / \mathrm{m} 1$ and $178.75 \pm 22.5$ $\mathrm{ng} / \mathrm{m} 1$ ) at $7 \mathrm{~h}$ after transdermal administration for men and women, respectively as presented in table 4 .

In general, the dermal evaluation showed that ondansetron gel was fully tolerated and a total rating of skin irritation was very low. In the plurality of assessments, Grade 0 (none) was observed. Common adverse effects were headache, back pain and dizziness for all volunteers and one subject suffer from the metallic taste. There are no serious adverse effects were considered treatmentrelated.

\section{Linearizing the ondansetron plasma concentration data using semi-log graph scale}

By plotting the intravenous plasma concentration data onto the semi-log graph scale, we can obtain a straight line which indicates the elimination phase and the drug occupies one compartment pharmacokinetics (40) as shown in fig. 5a. While in case of extravascular dose (transdermal gel) the two processes of absorption and elimination occur in parallel and at late times in graphs, absorption may be complete and we see virtually clear elimination phase (47) as shown in fig. 5 b, c, and d

Table 4: Pharmacokinetics parameters (a) of ondansetron gel administrated to women and men

\begin{tabular}{|c|c|c|c|c|}
\hline $\begin{array}{l}\text { Pharmacokinetics } \\
\text { parameter (a) }\end{array}$ & $\begin{array}{l}\text { Transdermal gel } \\
\text { male }\end{array}$ & $\begin{array}{l}\text { Transdermal gel } \\
\text { female }\end{array}$ & P-value & Significance of the difference (c) \\
\hline $\mathrm{C}_{\max }(\mathrm{ng} / \mathrm{ml})$ & $690.27 \pm 0.065$ & $522.65 \pm 0.098$ & $>0.05$ & Ns \\
\hline $\mathrm{T}_{\max }(\mathrm{h})$ & 3 & 3.5 & $>0.05$ & Ns \\
\hline $\mathrm{K}_{\mathrm{a}}\left(\mathrm{h}^{-1}\right)$ & $0.893 \pm 0.050$ & $0.70 \pm 0.043$ & $<0.01$ & $* *$ \\
\hline $\mathrm{t}_{1 / 2 \mathrm{a}}(\mathrm{h})$ & $0.779 \pm 0.043$ & $0.994 \pm 0.061$ & $<0.01$ & $* *$ \\
\hline $\mathrm{K}_{\mathrm{el}}\left(\mathrm{h}^{-1}\right)$ & $0.732 \pm 0.07$ & $0.357 \pm 0.148$ & 0.05 & * \\
\hline $\mathrm{t}_{1 / 2 \mathrm{el}}(\mathrm{h})$ & $0.955 \pm 0.091$ & $2.343 \pm 0.972$ & $>0.05$ & Ns \\
\hline AUC $_{0-\infty}(\mu \mathrm{g} . \mathrm{h} / \mathrm{ml})$ & $3.333 \pm 0.468$ & $3.176 \pm 0.071$ & $>0.05$ & Ns \\
\hline $\operatorname{AUMC}_{0-\infty}\left(\mu \mathrm{g} . \mathrm{h}^{2} / \mathrm{ml}\right)$ & $11.65 \pm 1.93$ & $15.65 \pm 3.184$ & $>0.05$ & Ns \\
\hline $\mathrm{MRT}_{0-\infty}(\mathrm{h})$ & $3.483 \pm 0.090$ & $4.952 \pm 1.113$ & $>0.05$ & Ns \\
\hline $\mathrm{Cl}_{\mathrm{T}}(\mathrm{L} / \mathrm{h})$ & $2.801 \pm 0.96$ & $2.705 \pm 0.155$ & $>0.05$ & Ns \\
\hline $\mathrm{V}_{\mathrm{d}}$ (liter) & $5.606 \pm 0.956$ & $6.477 \pm 0.155$ & $>0.05$ & Ns \\
\hline
\end{tabular}

${ }^{a}$ mean $\pm S D(n=3),{ }^{b} C_{\max }$ : maximum plasma concentration, $T_{\max }$ : time to reach $\mathrm{C}_{\max }, \mathrm{K}_{\mathrm{a}}$ : absorption rate constant, $\mathrm{t}_{1 / 2 \mathrm{a}}$ : absorption half-life, $\mathrm{K}_{\mathrm{el}}$ : elimination rate constant, $\mathrm{t}_{1 / 2}$ : elimination half-life, AUC: area under the ondansetron plasma concentration versus time curve, AUMC: area under the moment vs. time curve, MRT: mean residence time, Cl: clearance, $\mathrm{V}_{\mathrm{d}}$ : volume of distribution, F: fraction absorbed (bioavailability). chighly significant ${ }^{* * *}$ p 0.001 , moderate significant ${ }^{* *}$ p 0.01 , mild significant ${ }^{*}$ p 0.05 , non-significant NS p $>0.0$

\section{The antiemetic effect of ondansetron gel in cisplatin-induced emesis in rats}

American Society of Clinical Oncology guidelines classified cisplatin as the highest emetic risk group as it causes acute and delayed vomiting [19]. Acute vomiting mainly occurs within a few minutes to several hours next to cisplatin administration and usually resolves within the first $24 \mathrm{~h}$. Delayed vomiting develops after $24 \mathrm{~h}$ next to cisplatin administration and continues for 6-7 d [20].

Signs and mortality rates detected due to cisplatin injection in rats and the effect of ondansetron gel

All groups received cisplatin of $5 \mathrm{mg} / \mathrm{kg}$ dose suffered from most common side effects caused by it as general drowsiness, fatigue, loss of appetite and low locomotor activity like horizontal movement, mobility, and rearing during first $24 \mathrm{~h}$ after injection [48]. This result is in agreement with Malik et al. [49] who reported the influence of cisplatin on locomotors activity on rats after administration of $6 \mathrm{mg} / \mathrm{kg}$ cisplatin on day 2 post-injection compared to control group. They suggested that the lowering in locomotor activity might be a primary influence of cisplatin [50] or secondary to "nausea" or visceral malaise; the decrease in food intake might be attributed to nausea or to a reduction in locomotor activity.

From day 3-5 the feces of the cisplatin group was constipated grey in color compared with the control group, and on day 5 the feces become black and soft and convert to dark watery diarrhea in late 
days before the death of rats. Also, the rats suffering from nosebleeds and red spots on the skin of the head, neck and lower parts of legs due to reducing the number of platelets, alopecia, dry skin and dehydration. Also, there are muscle weakness and paralysis leading to death within $24 \mathrm{~h}$.

About $25 \%$ of rats receiving cisplatin without ondansetron gel died at day 5 of experiment and $100 \%$ of this group died at day 7 of the experiment, while another group which receiving cisplatin and ondansetron gel began to die at day 6 and $50 \%$ of rats still alive up to day 15 of the experiment.

Also, the previous signs also observed in the groups receiving cisplatin of $10 \mathrm{mg} / \mathrm{kg}$ dose but more aggressive and accelerated after day 3 of the experiment and all rats died on days 4 and 5 . While, the blank group receiving ondansetron gel did not show any specific signs like irritation, redness, drowsiness or fatigue and preserves the same activity comparing to the control group.

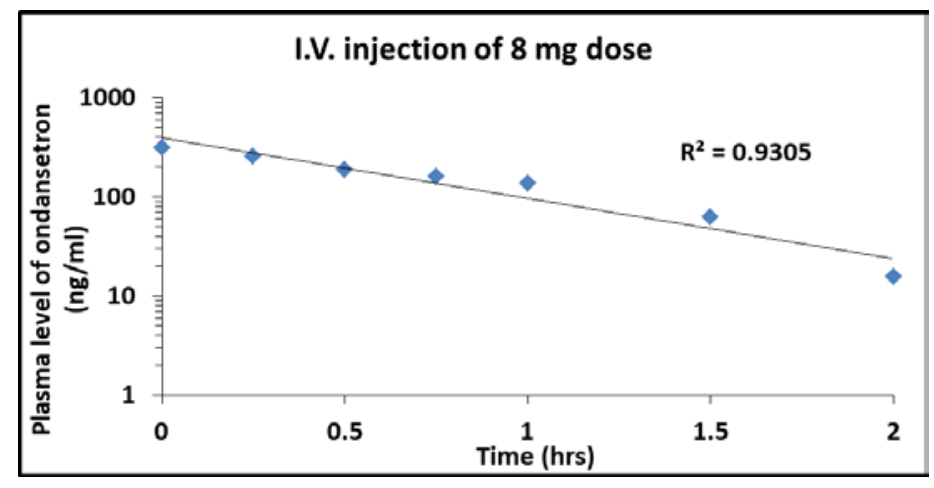

a-I. V. injection of $8 \mathrm{mg}$ dose

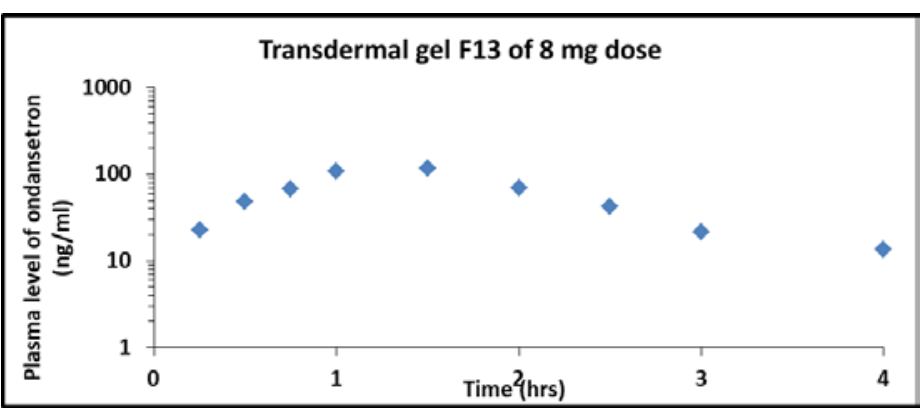

b-Transdermal gel F13 of $8 \mathrm{mg}$ dose in rabbits

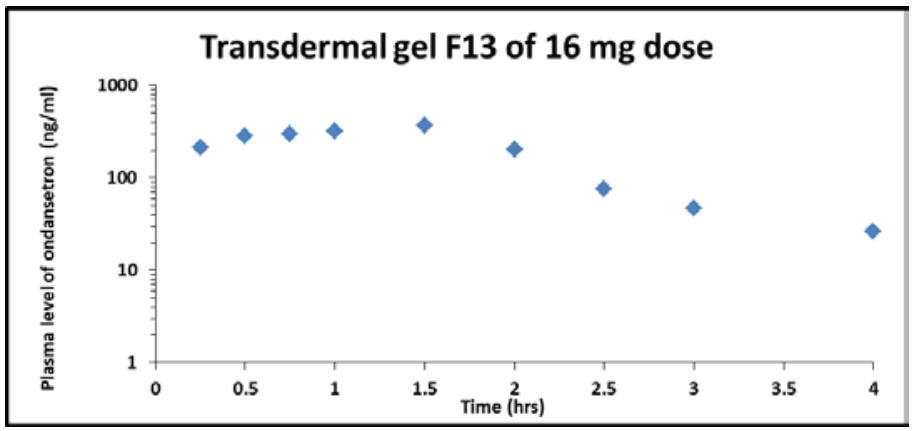

c-Transdermal gel F13 of 16 mg dose in rabbits

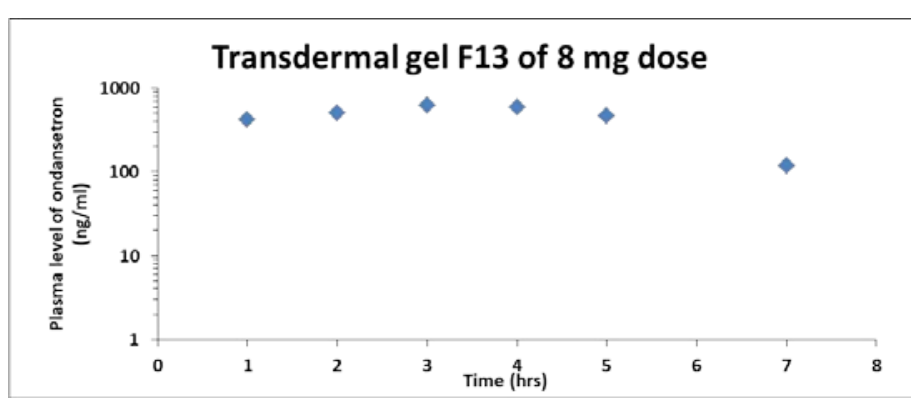

d-Transdermal gel of F13 of $8 \mathrm{mg}$ dose in humans

Fig. 5: Semi-log plot of ondansetron plasma concentration against time curve following administration of (a) marketed I. V. injection, (b) transdermal administration of $8 \mathrm{mg}$ dose in rabbits, (c) transdermal administration of $16 \mathrm{mg}$ dose in rabbits and (d) transdermal administration of $8 \mathrm{mg}$ dose in humans 


\section{Effect of ondansetron on cisplatin-induced body weight loss}

Cisplatin produced hypophagia and weight loss in all rats but these symptoms of illness were less severe in rats which had been administrated ondansetron gel than those did not have [51]

The results show that the body weight loss was increased in a dosedependent manner, as the higher cisplatin tested dose $(10 \mathrm{mg} / \mathrm{kg})$ rats show more weight loss compared to smaller dose and these results are in good harmony with data obtained by Cabezos et al. [52]
The two groups receiving cisplatin injection induce significant loss of animal's body weight of about 13.43 and $18 \%$ for 5 and $10 \mathrm{mg} / \mathrm{kg}$ doses, respectively at day 5 of an experiment comparing to 7.89 and $14.75 \%$ for groups receiving ondansetron gel ( $p<0.05)$.

Also, the groups receive $5 \mathrm{mg} / \mathrm{kg}$ cisplatin induces significant loss of animal's body weight of about $17.36 \%$ for $7 \mathrm{~d}$ of an experiment compared to $10.6 \%$ for ondansetron gel group receiving ( $p<0.001$ ) as demonstrated in tables 5-6 and (fig. 6a, b, c, and d).

Table 5: Effect of ondansetron gel formulation (F13) on body weight change (grams) of rats administered cisplatin (5 mg/kg, i. p.)

\begin{tabular}{lllll}
\hline Days & Control & Control+ondansetron gel & Cisplatin (5 mg/kg) I. P. & Cisplatin (5 mg/kg) I. P. +ondansetron gel \\
\hline 0 & $186.42 \pm 1.66$ & $185.10 \pm 1.15$ & $183.67 \pm 3.79$ & $184.95 \pm 2.92$ \\
1 & $181.33 \pm 1.24$ & $179.69 \pm 1.15$ & $180.48 \pm 1.50$ & $184.09 \pm 3.82$ \\
2 & $179.52 \pm 1.16$ & $181.42 \pm 1.67$ & $176.33 \pm 1.15$ & $180.10 \pm 3.02$ \\
3 & $180.84 \pm 2.16$ & $180.71 \pm 1.86$ & $170.02 \pm 2.11^{\mathrm{c}}$ & $180.21 \pm 3.11^{* * *}$ \\
4 & $181.22 \pm 2.64$ & $178.57 \pm 3.50$ & $167.63 \pm 0.55^{\mathrm{c}}$ & $176.89 \pm 2.85^{* * *}$ \\
5 & $182.32 \pm 1.82$ & $182.43 \pm 1.68$ & $159.08 \pm 1.81^{\mathrm{c}}$ & $170.34 \pm 2.41^{\mathrm{c}, * *}$ \\
6 & $183.50 \pm 2.29$ & $180.08 \pm 2.13$ & $157.42 \pm 4.88^{\mathrm{c}}$ & $164.74 \pm 2.69^{\mathrm{c}, * *}$ \\
7 & $181.59 \pm 4.13$ & $180.59 \pm 2.90$ & $151.77 \pm 2.92^{\mathrm{c}}$ & $165.29 \pm 2.36^{\mathrm{c}, * *}$ \\
8 & $185.33 \pm 2.52$ & $182.09 \pm 2.14$ & Died & $162.50 \pm 1.32^{\mathrm{c}}$ \\
9 & $184.23 \pm 2.25$ & $184.93 \pm 2.03$ & Died & $161.30 \pm 3.93^{\mathrm{c}}$ \\
\hline
\end{tabular}

${ }^{\text {aP }}<0.05,{ }^{\text {b }} \mathrm{P}<0.01,{ }^{\text {c }} \mathrm{P}<0.001$ vs. control group, ${ }^{*} \mathrm{P}<0.05,{ }^{* *} \mathrm{P}<0.01,{ }^{* * *} \mathrm{P}<0.001$ vs. cisplatin group.

Table 6: Effect of ondansetron gel formulation (F13) on body weight change (grams) of rats administered cisplatin (10 mg/kg, i. p.)

\begin{tabular}{llll}
\hline Days & Control & Cisplatin (10 $\mathbf{~ m g} / \mathbf{k g}) \mathbf{I}$. P. & Cisplatin (10 mg/kg) I. P. +ondansetron gel \\
\hline 0 & $186.42 \pm 1.66$ & $184.18 \pm 4.06$ & $184.98 \pm 1.36$ \\
1 & $181.33 \pm 1.24$ & $176.26 \pm 3.33$ & $179.07 \pm 2.07$ \\
2 & $179.52 \pm 1.16$ & $164.44 \pm 5.09^{\mathrm{c}}$ & $169.34 \pm 1.12^{\mathrm{c}}$ \\
3 & $180.84 \pm 2.16$ & $158.74 \pm 4.03^{\mathrm{c}}$ & $165.24 \pm 0.96^{\mathrm{c},{ }^{*}}$ \\
4 & $181.22 \pm 2.64$ & $153.78 \pm 2.86^{\mathrm{c}}$ & $163.90 \pm 1.33^{\mathrm{c}, * *}$ \\
5 & $182.32 \pm 1.82$ & $151.02 \pm 3.02^{\mathrm{c}}$ & $157.68 \pm 1.71^{\mathrm{c}, *}$ \\
\hline
\end{tabular}

${ }^{\text {aP }}<0.05$, bP $<0.01,{ }^{\text {c }} \mathrm{P}<0.001$ vs. control group, ${ }^{*} \mathrm{P}<0.05,{ }^{* *} \mathrm{P}<0.01,{ }^{* * *} \mathrm{P}<0.001$ vs. cisplatin group.

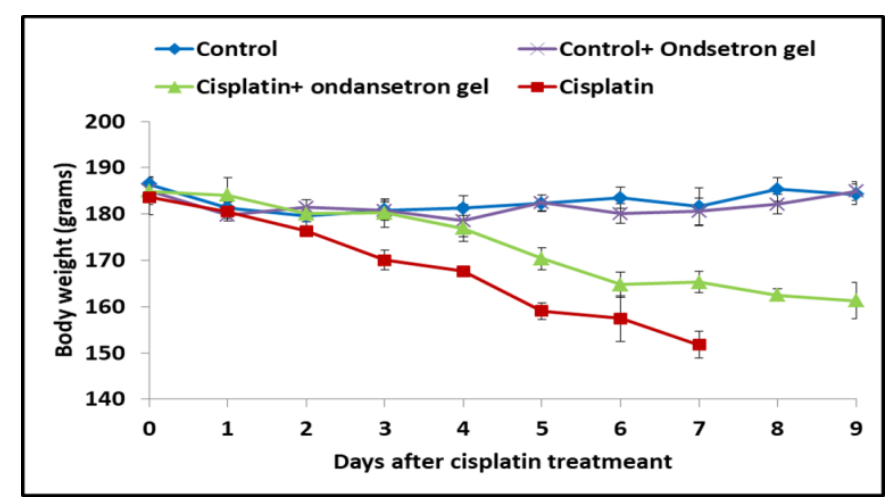

a-After administration of cisplatin ( $5 \mathrm{mg} / \mathrm{kg}$, i. p.)

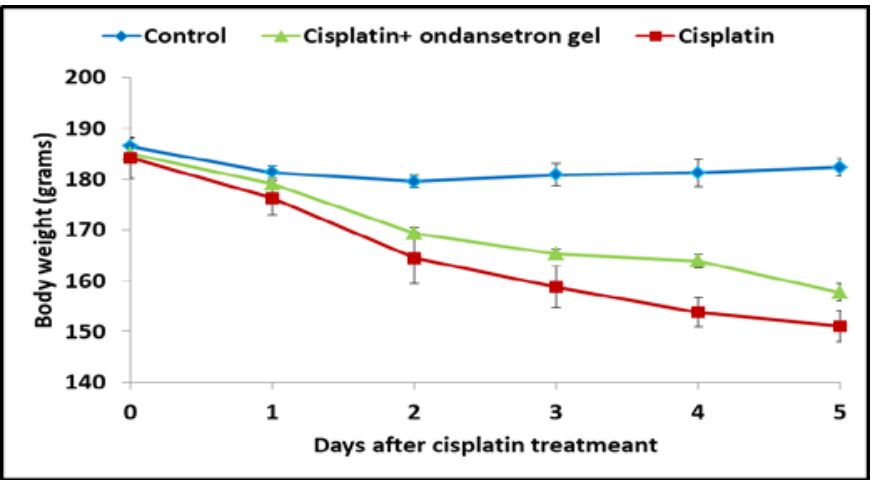

b-After administration of cisplatin $(10 \mathrm{mg} / \mathrm{kg}$, i. p.) 


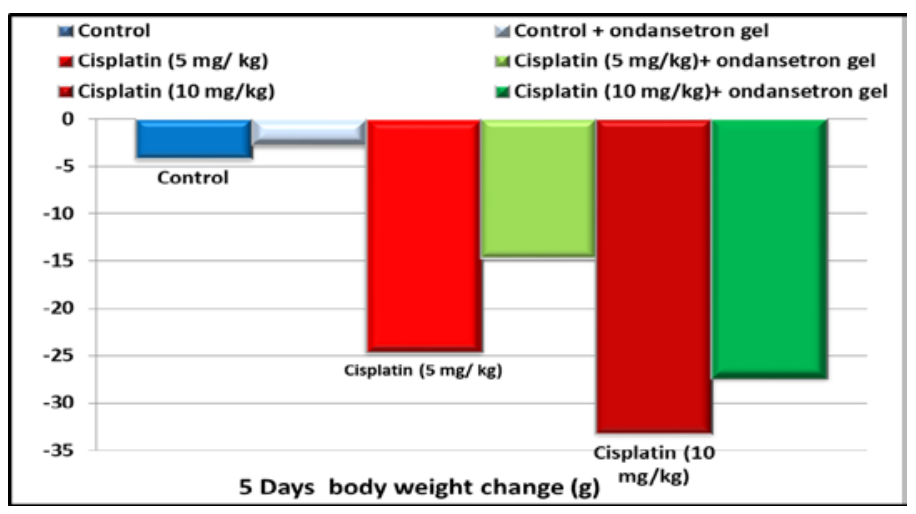

c- After $5 \mathrm{~d}$ of the experiment

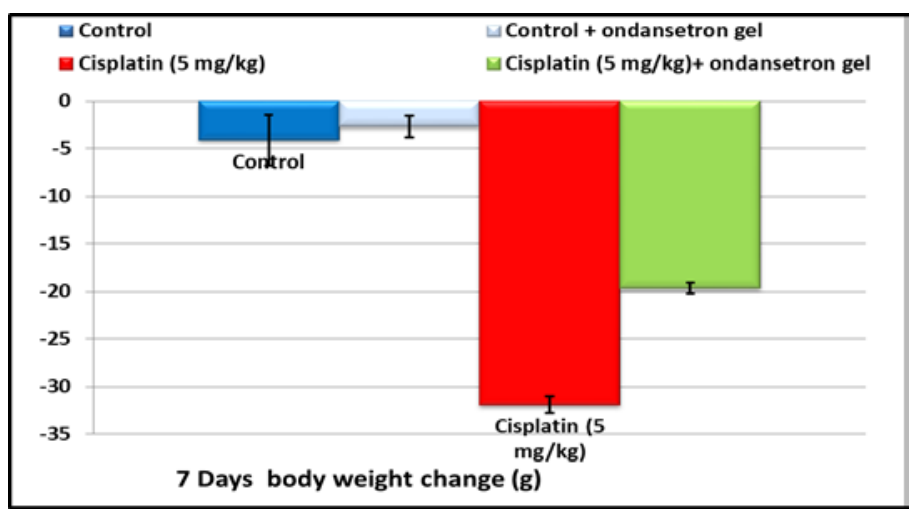

d-After $7 \mathrm{~d}$ of the experiment

Fig. 6: Effect of ondansetron gel formulation (F13) on body weight change of rats (a) administered cisplatin (5 mg/kg, i. p.), (b) administered cisplatin (10 mg/kg, i. p.), (c)after $5 \mathrm{~d}$ of the experiment and (d) after $7 \mathrm{~d}$ of the experiment

\section{Effect of ondansetron on the nutrition profile of cisplatin treating rats}

\section{Water consumption}

After adaptation period, control rats consume daily amount of $23.46 \pm 5 \mathrm{ml}$ of water and intraperitoneal administration of cisplatin $(5 \mathrm{mg} / \mathrm{kg})$ make a significant decrease in daily water consumption to average $11.8 \pm 7.8 \mathrm{ml}$ except at day 2 and 3 the results show increasing in water consumption due to the nephrotoxicity which is a current side effect of cisplatin treatment [53] and increased water intake has been noted in several studies [51].

These results are in good consent with De Jonghe et al. [51] who found that kaolin consumption ameliorates cisplatin-induced reductions in food but not water intake. This might be explained by the different mechanisms that underlie food and water transit and absorption in the gut. While the daily water amount consumed by rats significantly elevated to about $21.17 \pm 4.7$ by using ondansetron gel comparing with cisplatin only $(\mathrm{p}<0.05)$ as shown in (fig. $7 \mathrm{a})$ and table 7 .

Intraperitoneal administration of cisplatin of a dose $(10 \mathrm{mg} / \mathrm{kg})$ make a significant decrease in daily water consumption to average $7 \pm 11.5 \mathrm{ml}$ in nearly all days and the using of ondansetron gel significantly elevate the volume of water consumed by rats to 11.6 $\pm 8.7(\mathrm{p}<0.05)$ as elucidated in (fig. $7 \mathrm{~b})$ and table 8 and this result is in agreement with Liu et al. [44] who reported that the using dose of cisplatin more than $5 \mathrm{mg} / \mathrm{kg}$ cause increase in gastric contents as well as decreased food and water intake at $48 \mathrm{~h}$ postcisplatin treatment. Further support by the studies of Bradner and Schurig [54] and Olver et al. [55] in mice showing a dose-related decrease in water intake due to an increase in the weight of gastric contents measured at 24 or $48 \mathrm{~h}$ after cisplatin. This effect was obtained with other cytotoxic anticancer drugs in mice and rats [56].

Table 7: Effect of ondansetron gel formulation (F13) on the change of water consumption (ml) induced by cisplatin (5 mg/kg, i. p.)

\begin{tabular}{lllll}
\hline Days & Control & Control+ondansetron gel & Cisplatin (5 mg/kg) I. P. & Cisplatin (5 mg/kg) I. P. +ondansetron gel \\
\hline 0 & $26.75 \pm 2.75$ & $28.42 \pm 2.27$ & $27.50 \pm 2.50$ & $26.00 \pm 3.00$ \\
1 & $30.50 \pm 2.63$ & $35.00 \pm 7.00$ & $15.50 \pm 1.50^{\mathrm{c}}$ & $20.00 \pm 2.00^{\mathrm{c}}$ \\
2 & $22.75 \pm 2.25$ & $31.42 \pm 6.50$ & $27.00 \pm 3.00$ & $25.83 \pm 2.02$ \\
3 & $25.25 \pm 2.50$ & $29.92 \pm 10.0$ & $26.33 \pm 3.51$ & $25.17 \pm 1.76^{* * *}$ \\
4 & $27.75 \pm 4.88$ & $28.58 \pm 6.50$ & $9.33 \pm 3.25^{\mathrm{c}}$ & $16.67 \pm 2.02^{\mathrm{c}, * *}$ \\
5 & $25.75 \pm 1.75$ & $34.42 \pm 9.50$ & $4.00 \pm 2.00$ & $18.67 \pm 2.52^{* * *}$ \\
6 & $20.33 \pm 1.53$ & $29.44 \pm 0.51$ & $5.50 \pm 2.18^{\mathrm{c}}$ & $29.00 \pm 3.00^{* * *}$ \\
7 & $14.33 \pm 1.53$ & $28.64 \pm 0.56$ & $4.00 \pm 0.50^{\mathrm{c}}$ & $17.00 \pm 2.00$ \\
8 & $21.17 \pm 1.76$ & $30.72 \pm 1.11$ & Died & $15.00 \pm 2.50$ \\
9 & $20.00 \pm 2.00$ & $29.67 \pm 4.73$ & Died & \\
\hline
\end{tabular}

aP $<0.05$, b $\mathrm{P}<0.01,{ }^{\text {c }} \mathrm{P}<0.001$ vs. control group, ${ }^{*} \mathrm{P}<0.05,{ }^{* *} \mathrm{P}<0.01,{ }^{* * *} \mathrm{P}<0.001$ vs. cisplatin group. 


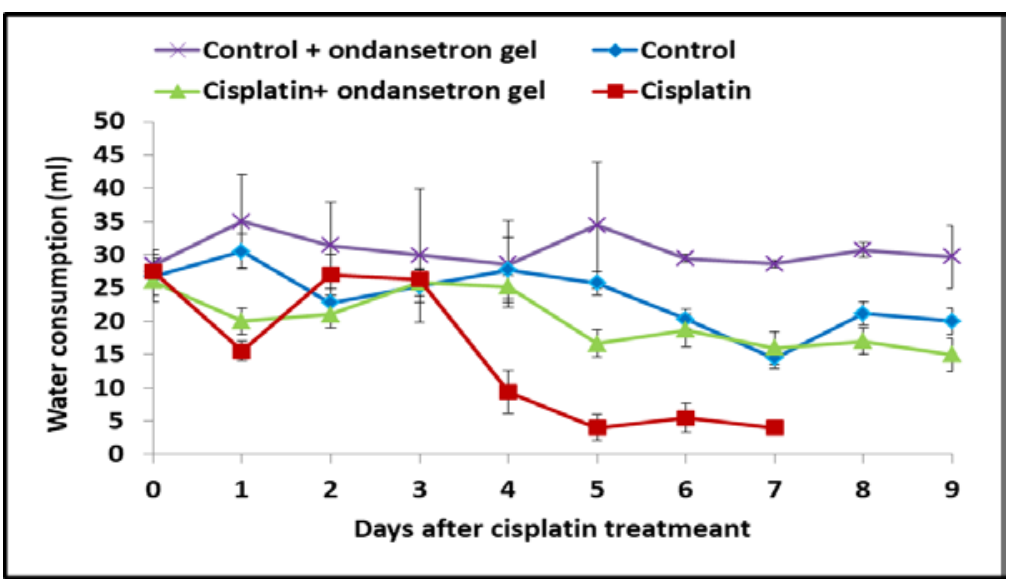

a-cisplatin ( $5 \mathrm{mg} / \mathrm{kg}$, i. p.)

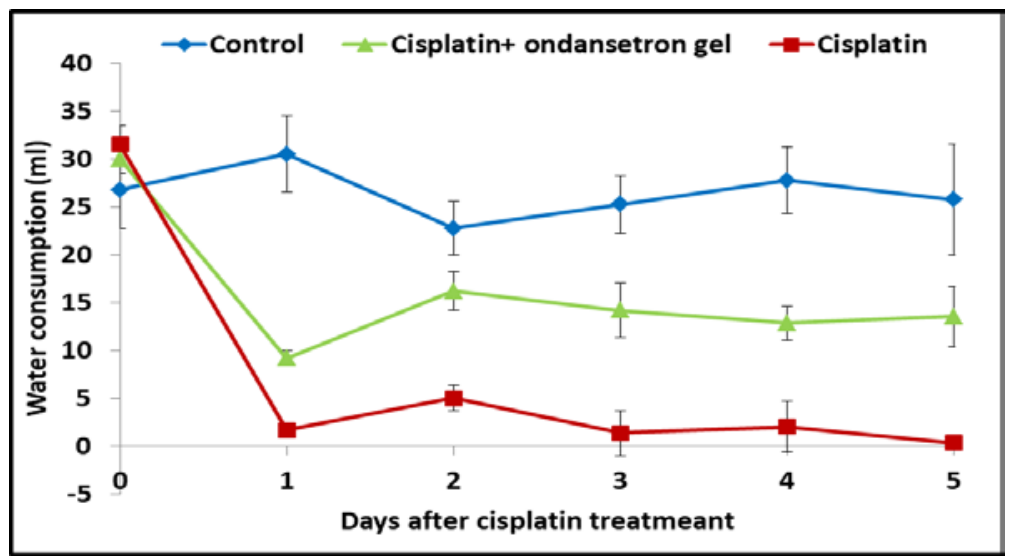

b-cisplatin (10 mg/kg, i. p.)

Fig. 7: Effect of ondansetron gel formulation (F13) and (a) cisplatin (5 mg/kg, i. p.) and (b) cisplatin (10 mg/kg, i. p.) on water consumption $(\mathrm{ml})$ in rats

Table 8: Effect of ondansetron gel formulation (F13) on the change of water consumption (ml) induced by cisplatin (10 mg/kg, i. p.)

\begin{tabular}{llll}
\hline Days & Control & Cisplatin $(\mathbf{1 0 ~} \mathbf{~ m g} / \mathbf{k g}) \mathbf{I}$. P. & Cisplatin (10 mg/kg) I. P. +ondansetron gel \\
\hline 0 & $26.75 \pm 2.75$ & $31.50 \pm 2.50$ & $30.00 \pm 3.50$ \\
1 & $30.50 \pm 2.63$ & $1.67 \pm 0.58^{\mathrm{c}}$ & $9.17 \pm 0.76^{\mathrm{c}, * *}$ \\
2 & $22.75 \pm 2.25$ & $5.00 \pm 1.32^{\mathrm{c}}$ & $16.17 \pm 2.02^{\mathrm{a},{ }^{* * *}}$ \\
3 & $25.25 \pm 2.50$ & $1.33 \pm 2.31^{\mathrm{c}}$ & $14.17 \pm 2.84^{\mathrm{c}^{* * *}}$ \\
4 & $27.75 \pm 4.88$ & $2.00 \pm 2.65^{\mathrm{c}}$ & $12.83 \pm 1.76^{\mathrm{c}^{, * * *}}$ \\
5 & $25.75 \pm 1.75$ & $0.33 \pm 0.58^{\mathrm{c}}$ & $13.50 \pm 3.12^{\mathrm{c}^{* * *}}$ \\
\hline
\end{tabular}

aP $<0.05$, bP $<0.01$, c $\mathrm{P}<0.001$ vs. control group, ${ }^{*} \mathrm{P}<0.05,{ }^{* *} \mathrm{P}<0.01,{ }^{* * *} \mathrm{P}<0.001$ vs. cisplatin group.

\section{Food consumption}

Tables 9-10 and (fig. 8a, b) showed that after injection of cisplatin, normal feed consumption in the cisplatin groups significantly decreased when compared with the control group after $24 \mathrm{~h}$ of injection $(\mathrm{P}<0.01)$. Moreover, this decrease was reduced by ondansetron administration after the third day of injection $(\mathrm{P}<0.05)$ in the case of $5 \mathrm{mg} / \mathrm{kg}$ cisplatin dose. Similarly, in case of $10 \mathrm{mg} / \mathrm{kg}$ cisplatin dose, there is slight attenuation of food intake by using ondansetron gel comparing with cisplatin group and these results are in harmony with data obtained by Cabezos et al. [52] who reports that administration of cisplatin prompted a significant decrease in food ingestion in the $24 \mathrm{~h}$ instantly after administration due to severe anorexia.

\section{Kaolin consumption}

In case of $5 \mathrm{mg} / \mathrm{kg}$ dose of cisplatin, there is a significant increase in kaolin consumption during first $48 \mathrm{~h}$ after injection and the changes in of kaolin intake were remarkably recovered on day 3, although the body weight loss was still preserved as demonstrated in table 11 and (fig. 9a).

Further administration of cisplatin did not change the kaolin consumption and still maintained at the normal level. This explains the change of quality of rats feces during the experiment period as cisplatin produces gastric stasis and diarrhea $[49,57,58]$ and clay possesses toxin-binding properties $[59,60]$ as an anti-diarrhea drug [61]. Thus, kaolin consumption could limit the side effects of cisplatin on the GI tract, lessening the severity of distress experienced by the animal. Pre-treatment with the ondansetron gel significantly reduced the cisplatin-induced increase in kaolin consumption to the normal levels.

While in the case of $10 \mathrm{mg} / \mathrm{kg}$ dose of cisplatin the level of kaolin was increased significantly on day $4(400.001)$ comparing to both control and ondansetron group as elucidated in table 12 and (fig. 9b). Delayed access of rats to kaolin may be one of the reasons for 
rapid death due to increasing the severity of illness symptoms like weight loss and hypophagia. These data suggest that kaolin consumption following cisplatin not only indicates sickness but also plays a therapeutic role by diminishing the degree of malaise experienced by the rat and/or enhancing the rate of recovery as reported by Riezzo G, et al. [58].

\section{Effect of ondansetron gel alone on rats}

There is no significant difference in changing in body weight and water, food, and kaolin consumption comparing with the control group as shown in (fig. 6a, 7a, 8a, and 9a) and tables 5, 7, 9 and 11. Also, there were no important signs and side effects reported by this group.
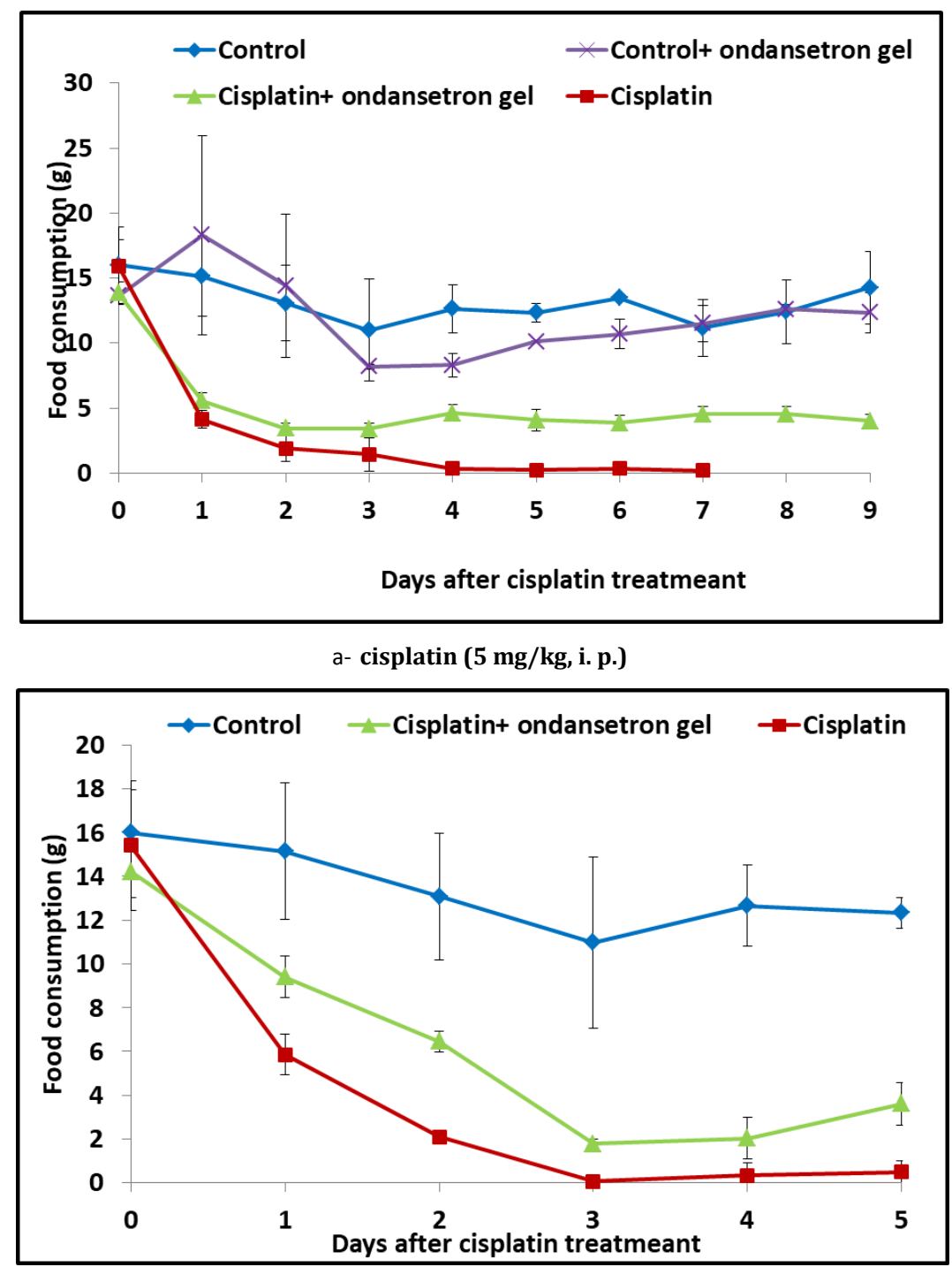

b- cisplatin (10 mg/kg, i. p.)

Fig. 8: Effect of ondansetron gel formulation (F13) and (a) cisplatin (5 mg/kg, i. p.) and (b) cisplatin (10 mg/ $\mathrm{kg}$, i. p.) on food consumption (grams) in rats

Table 9: Effect of ondansetron gel formulation (F13) on the change of food consumption (grams) induced by cisplatin (5 mg/kg, i. p.)

\begin{tabular}{lllll}
\hline Days & Control & Control+ondansetron gel & Cisplatin (5 mg/kg) I. P. & Cisplatin (5 mg/kg) I. P. +ondansetron gel \\
\hline 0 & $15.99 \pm 1.97$ & $13.63 \pm 0.03$ & $15.92 \pm 2.98$ & $13.04 \pm 1.56$ \\
1 & $15.15 \pm 3.12$ & $18.30 \pm 7.66$ & $4.14 \pm 0.68^{\mathrm{c}}$ & $5.56 \pm 0.59 \mathrm{a}$ \\
2 & $13.07 \pm 2.89$ & $14.43 \pm 5.50$ & $1.90 \pm 1.01^{\mathrm{c}}$ & $3.44 \pm 0.43^{\mathrm{c}}$ \\
3 & $10.98 \pm 3.92$ & $8.18 \pm 0.17$ & $1.42 \pm 1.32^{\mathrm{c}}$ & $3.41 \pm 0.41^{\mathrm{c}}$ \\
4 & $12.66 \pm 1.85$ & $8.32 \pm 0.91$ & $0.36 \pm 0.25^{\mathrm{c}}$ & $4.63 \pm 0.61^{\mathrm{c}^{*},}$ \\
5 & $12.33 \pm 0.70$ & $10.11 \pm 0.10$ & $0.24 \pm 0.02^{\mathrm{c}}$ & $3.80 \pm 0.35^{\mathrm{c},{ }^{*}}$ \\
6 & $13.42 \pm 0.14$ & $10.70 \pm 1.12$ & $0.01 \pm 0.01^{\mathrm{c}}$ & $3.78 \pm 0.488^{\mathrm{c}}$ \\
7 & $10.160 \pm 1.62$ & $11.51 \pm 1.39$ & $0.18 \pm 0.28^{\mathrm{c}}$ & $4.55 \pm 0.55^{\mathrm{c}, *}$ \\
8 & $12.400 \pm 2.44$ & $12.60 \pm 0.35$ & Died & $4.54 \pm 0.55^{\mathrm{c}, * *}$ \\
9 & $14.210 \pm 2.08$ & $12.33 \pm 1.53$ & Died & $4.00 \pm 0.50^{\mathrm{c}^{*}}$ \\
\hline
\end{tabular}

aP $<0.05$, b $<<0.01,{ }^{c} \mathrm{P}<0.001$ vs. control group, ${ }^{*} \mathrm{P}<0.05,{ }^{* *} \mathrm{P}<0.01,{ }^{* * *} \mathrm{P}<0.001$ vs. cisplatin group. 
Table 10: Effect of ondansetron gel formulation (F13) on the change of food consumption (grams) induced by cisplatin (10 mg/kg, i. p.)

\begin{tabular}{llll}
\hline Days & Control & Cisplatin (10 $\mathbf{~ m g} / \mathbf{k g}) \mathbf{~ I . ~ P . ~}$ & Cisplatin (10 mg/kg) I. P. +ondansetron gel \\
\hline 0 & $15.99 \pm 1.97$ & $15.40 \pm 2.94$ & $14.21 \pm 1.21$ \\
1 & $15.15 \pm 3.12$ & $5.85 \pm 0.93^{\mathrm{c}}$ & $9.40 \pm 0.96^{\mathrm{c}}$ \\
2 & $13.07 \pm 2.89$ & $2.09 \pm 0.21^{\mathrm{c}}$ & $6.45 \pm 0.48^{\mathrm{c},{ }^{*}}$ \\
3 & $10.98 \pm 3.92$ & $0.07 \pm 0.12^{\mathrm{c}}$ & $1.78 \pm 0.20^{\mathrm{c}}$ \\
4 & $12.66 \pm 1.85$ & $0.33 \pm 0.58^{\mathrm{c}}$ & $2.03 \pm 0.95^{\mathrm{c}}$ \\
5 & $12.33 \pm 0.70$ & $0.50 \pm 0.50^{\mathrm{c}}$ & $3.60 \pm 0.96^{\mathrm{c}}$ \\
\hline
\end{tabular}

aP $<0.05$, bP $<0.01,{ }^{c} \mathrm{P}<0.001$ vs. control group., ${ }^{*} \mathrm{P}<0.05,{ }^{* *} \mathrm{P}<0.01,{ }^{* * *} \mathrm{P}<0.001$ vs. cisplatin group.
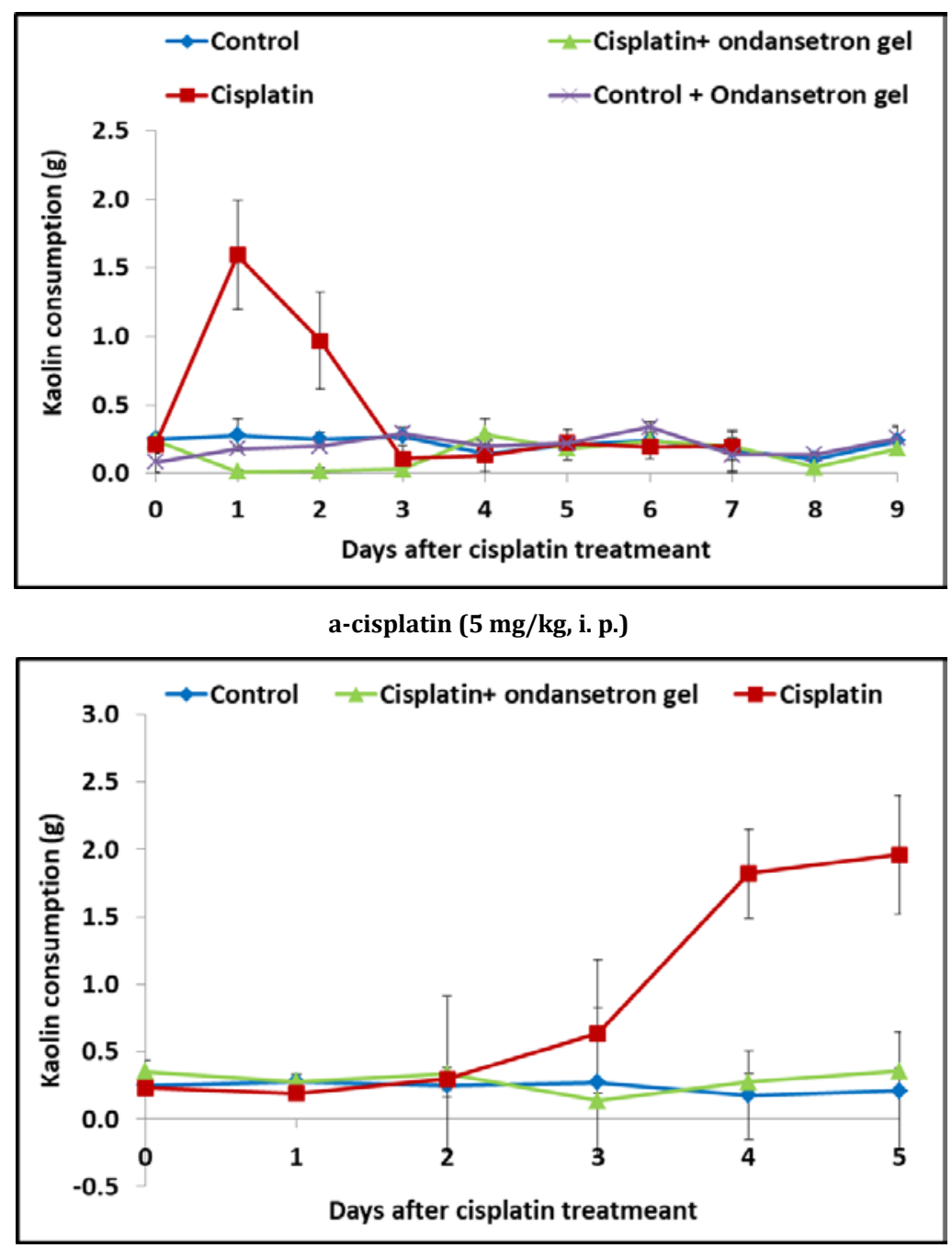

b-cisplatin (10 mg/kg, i. p.)

Fig. 9: Effect of ondansetron gel formulation (F13) and (a) cisplatin (5 mg/kg, i. p.) and (b) cisplatin (10 mg/ $\mathrm{kg}$, i. p.) on the Kaolin consumption (grams) in rats

Table 11: Effect of ondansetron gel formulation (F13) on the change of Kaolin consumption (grams) induced by cisplatin (5 mg/kg, i. p.)

\begin{tabular}{lllll}
\hline Days & Control & Control+ondansetron gel & Cisplatin (5 mg/kg) I. P. & Cisplatin (5 mg/kg) I. P. +ondansetron gel \\
\hline 0 & $0.25 \pm 0.02$ & $0.08 \pm 0.08$ & $0.21 \pm 0.06$ & $0.24 \pm 0.07$ \\
1 & $0.28 \pm 0.12$ & $0.18 \pm 0.01$ & $1.59 \pm 0.40^{c}$ & $0.01 \pm 0.02^{* * *}$ \\
2 & $0.25 \pm 0.05$ & $0.20 \pm 0.02$ & $0.97 \pm 0.35^{\mathrm{c}}$ & $0.02 \pm 0.03^{* * *}$ \\
3 & $0.27 \pm 0.02$ & $0.29 \pm 0.04$ & $0.11 \pm 0.10$ & $0.03 \pm 0.03$ \\
4 & $0.15 \pm 0.15$ & $0.20 \pm 0.02$ & $0.13 \pm 0.12$ & $0.29 \pm 0.12$ \\
5 & $0.21 \pm 0.11$ & $0.22 \pm 0.02$ & $0.22 \pm 0.03$ & $0.18 \pm 0.03$ \\
6 & $0.24 \pm 0.10$ & $0.34 \pm 0.04$ & $0.20 \pm 0.09$ & $0.24 \pm 0.04$ \\
7 & $0.17 \pm 0.15$ & $0.14 \pm 0.13$ & $0.20 \pm 0.10$ & $0.20 \pm 0.04$ \\
8 & $0.10 \pm 0.05$ & $0.14 \pm 0.01$ & Died & $0.04 \pm 0.05$ \\
9 & $0.24 \pm 0.10$ & $0.26 \pm 0.10$ & Died & $0.18 \pm 0.03$ \\
\hline
\end{tabular}

${ }_{a}^{\mathrm{a}} \mathrm{P}<0.05,{ }^{\mathrm{b}} \mathrm{P}<0.01,{ }^{\mathrm{c}} \mathrm{P}<0.001$ vs. control group, ${ }^{*} \mathrm{P}<0.05,{ }^{* *} \mathrm{P}<0.01,{ }^{* * *} \mathrm{P}<0.001$ vs. cisplatin group. 
Table 12: Effect of ondansetron gel formulation (F13) on the change of Kaolin consumption (grams) induced by cisplatin (10 mg/kg, i. p.)

\begin{tabular}{llll}
\hline Days & Control & Cisplatin $(\mathbf{1 0 ~} \mathbf{~ m g} / \mathbf{k g})$ I. P. & Cisplatin (10 $\mathbf{~ m g} / \mathbf{k g})$ I. P. +ondansetron gel \\
\hline 0 & $0.25 \pm 0.05$ & $0.23 \pm 0.06$ & $0.35 \pm 0.08$ \\
1 & $0.28 \pm 0.17$ & $0.19 \pm 0.05$ & $0.28 \pm 0.03$ \\
2 & $0.25 \pm 0.05$ & $0.30 \pm 0.09$ & $0.33 \pm 0.58$ \\
3 & $0.27 \pm 0.02$ & $0.63 \pm 0.55$ & $0.14 \pm 0.06$ \\
4 & $0.18 \pm 0.19$ & $1.82 \pm 0.33^{c}$ & $0.28 \pm 0.07^{* * *}$ \\
5 & $0.21 \pm 0.21$ & $1.96 \pm 0.44^{\mathrm{c}}$ & $0.36 \pm 0.02^{* * *}$ \\
\hline
\end{tabular}

${ }^{a} \mathrm{P}<0.05,{ }^{b} \mathrm{P}<0.01,{ }^{c} \mathrm{P}<0.001$ vs. control group, ${ }^{*} \mathrm{P}<0.05,{ }^{* *} \mathrm{P}<0.01,{ }^{* * *} \mathrm{P}<0.001$ vs. cisplatin group.

\section{CONCLUSION}

Based on the high efficacy of transdermal ondansetron gel $(7 \% \mathrm{w} / \mathrm{w}$ sodium alginate) on the emesis induced by antineoplastic drugs and long-term efficiency, as well as a high bioavailability, the transdermal ondansetron gel could be a promising convenient system to relieve, prohibit or stop nausea and vomiting in patients taking chemotherapy or radiotherapy.

\section{AUTHORS CONTRIBUTIONS}

Elsayed A. Ibrahim designed the work, Mai M. Rasheedy carries out the laboratory work with guidance from Dina Fathallah and Mona M. El-Mahdy, Dina Fathallah wrote the article. All authors critically revised and approved the work for publication.

\section{FUNDING}

Nil

\section{CONFLICT OF INTERESTS}

None

\section{REFERENCES}

1. Patel DR, Joshi A, Patel HH, Stagni G. Development and in vivo evaluation of ondansetron gels for transdermal delivery. Drug Dev Ind Pharm 2015;41:1030-6.

2. Maraie NK, Almajidi YQ, Alshader A. Absolute and relative bioavailability study for the newly developed nasal nanoemulsion in situ gel of ondansetron $\mathrm{Hcl}$ in comparison to conventionally prepared in situ gel and intravenous dosage forms. Int J Appl Pharm 2018;10:105-9.

3. Atashkhoei S, Bilehjani E, Fakhari S, Hanieh F. Postoperative nausea and vomiting prophylaxis with ondansetron in diagnostic gynecologic laparoscopy: preemptive versus preventive method. AJARS 2017;5:1-9.

4. Tomasik E, Ziolkowska E, Kolodziej M, Szajewska H. Systematic review with meta-analysis: ondansetron for vomiting in children with acute gastroenteritis. Aliment Pharmacol Ther 2016;44:438-46.

5. Menaka M, Pandey VP, Anton SA. Colloidal dispersions as a potential nasal drug delivery system for ondansetron hydrochloride-in vitro and in vivo properties. Asian J Pharm Clin Res 2014;7:72-5.

6. O'Neil MJ. The merck index: an encyclopedia of chemicals, drugs, and biologicals: RSC Publishing; 2013. p. 1270.

7. Kumar A, Adhana S, Dwivedi P. A comparison of intravenous ondansetron and paloseron in preventing postoperative nausea and vomiting after laproscopic cholecystectomy-A randomized double-blind study. Asian J Pharm Clin Res 2018;11:128-31.

8. Khan S, Kataria P, Nakhat P, Yeole P. Taste masking of ondansetron hydrochloride by polymer carrier system and formulation of rapid-disintegrating tablets. AAPS PharmSciTech 2007;8:E127-33.

9. Rasheedy MM, El-Mahdy MM, Fathallah D, Ibrahim EA. Formulation and evaluation of ondansetron transdermal gels. Bull Pharm Sci Assiut 2017;40:57-70.

10. Panchagnula R, Thomas NS. Biopharmaceutics and pharmacokinetics in drug research. Int J Pharm 2000;201:131-50.

11. Emami J. In vitro-in vivo correlation: from theory to applications. J Pharm Pharm Sci 2006;9:169-89.
12. Leopold CS. How accurate is the determination of the relative bioavailability of transdermal drug formulations from pharmacodynamic response data? Pharm Acta Helv 1998;73:63-7.

13. Andrews PL, Rapeport WG, Sanger GJ. Neuropharmacology of emesis induced by anti-cancer therapy. Trends Pharmacol Sci 1988;9:334-41.

14. Kilpatrick GJ, Bunce KT, Tyers MB. HTT3 receptors. Med Res Rev 1990;10:441-75.

15. Tyers MB. 5-HT3 receptors and the therapeutic potential of 5HT3 receptor antagonists. Therapie 1991;46:431-5.

16. Sharma V, Arora S. Emesis during chemotherapy: A review on granisetron, its efficacy and delivery systems. Int J Curr Pharm Res 2015;7:11-8.

17. Minami M, Ogawa T, Endo T, Hamaue N, Hirafuji M, Yoshioka M, et al. Cyclophosphamide increases 5-hydroxytryptamine release from the isolated ileum of the rat. Res Commun Mol Pathol Pharmacol 1997;97:13-24.

18. Andrews PL, Horn CC. Signals for nausea and emesis: implications for models of upper gastrointestinal diseases. Auton Neurosci 2006;125:100-15.

19. Kris MG, Hesketh PJ, Somerfield MR, Feyer P, Clark Snow R, Koeller JM, et al. American society of clinical oncology guideline for antiemetics in oncology: update 2006. J Clin Oncol 2006;24:2932-47.

20. Kris MG, Gralla RJ, Clark RA, Tyson LB, O'Connell JP, Wertheim MS, et al. Incidence, course, and severity of delayed nausea and vomiting following the administration of high-dose cisplatin. J Clin Oncol 1985;3:1379-84.

21. Andrews P, Bhandari P. The 5-hydroxytryptamine receptor antagonists as antiemetics: preclinical evaluation and mechanism of action. Eur J Cancer 1993;29:S11-6.

22. Rudd JA, Naylor RJ. An interaction of ondansetron and dexamethasone antagonizing cisplatin-induced acute and delayed emesis in the ferret. Br J Pharmacol 1996;118:209-14.

23. Aapro MS. 5-HT3 receptor antagonists. An overview of their present status and future potential in cancer therapy-induced emesis. Drugs 1991;42:551-68.

24. Morrow GR, Hickok JT, Rosenthal SN. Progress in reducing nausea and emesis. Comparisons of ondansetron (Zofran), granisetron (Kytril), and tropisetron (Navoban). Cancer 1995;76:343-57.

25. Rudd JA, Jordan CC, Naylor RJ. Profiles of emetic action of cisplatin in the ferret: a potential model of acute and delayed emesis. Eur J Pharmacol 1994;262:R1-2.

26. King GL. Animal models in the study of vomiting. Can J Physiol Pharmacol 1990;68:260-8.

27. Takeda N, Hasegawa S, Morita M, Matsunaga T. Pica in rats is analogous to emesis: an animal model in emesis research. Pharmacol Biochem Behav 1993;45:817-21.

28. Saeki M, Sakai M, Saito R, Kubota H, Ariumi H, Takano Y, et al. Effects of HSP-117, a novel tachykinin NK1-receptor antagonist, on cisplatin-induced pica as a new evaluation of delayed emesis in rats. Japan J Pharmacol 2001;86:359-62.

29. Rudd JA, Yamamoto K, Yamatodani A, Takeda N. Differential action of ondansetron and dexamethasone to modify cisplatininduced acute and delayed kaolin consumption ("pica") in rats. Eur J Pharmacol 2002;454:47-52.

30. Yamamoto K, Matsunaga S, Matsui M, Takeda N, Yamatodani. A pica in mice as new model for the study of emesis. Methods and findings. Exp Clin Pharmacol 2002;24:135-8. 
31. Qureshi MJ, Ali J, Baboota S, Ahuja A, Mallikarjun C Pharmacokinetic study of a capsule-based chronomodulated drug delivery system of salbutamol sulphate in rabbits. Trop J Pharm Res 2014;13:17-22.

32. Karim S, Hay YK, Baie SH, Bukhari NI, Murtaza G. Study of comparative bioavailability of omeprazole pellets. Acta Pol Pharm 2014;71:463-8.

33. Mason JW, Selness DS, Moon TE, O'Mahony B, Donachie P, Howell J. Pharmacokinetics and repolarization effects of intravenous and transdermal granisetron. Clin Cancer Res 2012;18:2913-21.

34. Howell J, Smeets J, Drenth HJ, Gill D. Pharmacokinetics of a granisetron transdermal system for the treatment of chemotherapy-induced nausea and vomiting. J Oncol Pharm Pract 2009;15:223-31.

35. Koland M, Charyulu RN, Vijayanarayana K, Prabhu P. In vitro and in vivo evaluation of chitosan buccal films of ondansetron hydrochloride. Int J Pharm Investig 2011;1:164-71.

36. Sheshala R, Khan N, Chitneni M, Darwis Y. Formulation and in vivo evaluation of ondansetron orally disintegrating tablets using different superdisintegrants. Arch Pharm Res 2011:34:1945-56

37. Wu Z, Zhang $\mathrm{C}$, Yang $\mathrm{C}$, Zhang $\mathrm{X}$, Wu E. Simultaneous quantitative determination of norgestrel and progesterone in human serum by high-performance liquid chromatographytandem mass spectrometry with atmospheric pressure chemical ionization. Analyst 2000;125:2201-5.

38. Singh RK, Ramakrishna S, Gupta P. RP-HPLC method development and validation for simultaneous estimation of ranitidine hydrochloride and domperidone in combined tablet dosage form. Int J Pharm Sci Res 2010;1:77.

39. Chen FC, Wang LH, Guo J, Shi XY, Fang BX. Simultaneous determination of dexamethasone, ondansetron, granisetron, tropisetron, and azasetron in infusion samples by HPLC with DAD detection. J Anal Methods Chem 2017;2017:1-7.

40. Gibaldi M. Biopharmaceutics and clinical pharmaceutics. 4th edition ed. Philadelphia, USA; 1991. p. 147, 205, 337.

41. Mitchell D, Wells C, Hoch N, Lind K, Woods SC, Mitchell LK. Poison induced pica in rats. Physiol Behav 1976;17:691-7.

42. Aung HH, Mehendale SR, Xie JT, Moss J, Yuan CS. Methylnaltrexone prevents morphine-induced kaolin intake in the rat. Life Sci 2004;74:2685-91.

43. Liu YL, Malik N, Sanger GJ, Friedman MI, Andrews PL. Pica-a model of nausea? Species differences in response to cisplatin. Physiol Behav 2005;85:271-7.

44. Du Sert NP, Rudd J, Apfel C, Andrews PJCc, pharmacology. Cisplatin-induced emesis: systematic review and meta-analysis of the ferret model and the effects of 5-HT 3 receptor antagonists. Cancer Chemother Pharmacol 2011;67:667-86.

45. Shi J. Evaluating the various phases of cisplatin-induced emesis in rats. Oncol Lett 2014;8:2017-22.
46. Repetto MR, Repetto M. Concentrations in human fluids: 101 drugs affecting the digestive system and metabolism. J Toxicol Clin Toxicol 1999;37:1-9.

47. Ahmed TA. Basic pharmacokinetic concepts and some clinical applications: BoD-Books on Demand; 2015.

48. British Medical Association, Joint Formulary Committee (Great Britain), Pharmaceutical Society of Great Britain. British national formulary. Pharmaceutical Pr; 2003.

49. Malik NM, Liu YL, Cole N, Sanger GJ, Andrews PL. Differential effects of dexamethasone, ondansetron and a tachykinin NK1 receptor antagonist (GR205171) on cisplatin-induced changes in behaviour, food intake, pica and gastric function in rats. Eur J Pharmacol 2007;555:164-73.

50. Malik NM, Moore GB, Smith G, Liu YL, Sanger GJ, Andrews PL. Behavioural and hypothalamic molecular effects of the anticancer agent cisplatin in the rat: a model of chemotherapyrelated malaise? Pharmacol Biochem Behav 2006;83:9-20.

51. De Jonghe BC, Lawler MP, Horn CC, Tordoff MG. Pica as an adaptive response: Kaolin consumption helps rats recover from chemotherapy-induced illness. Physiol Behav 2009;97:87-90.

52. Cabezos P, Vera G, Martin Fontelles M, Fernandez Pujol R, Abalo R, Motility. Cisplatiinduced gastrointest inal dysmotility is aggravated after chronic administration in the rat. Comparison with pica. Neurogastroenterol Motil 2010;22:797-e225.

53. Gordon JA, Peterson LN, Anderson RJ. Water metabolism after cisplatin in the rat. Am J Physiol 1982;243:F36-43.

54. Bradner WT, Schurig JE. Toxicology screening in small animals. Cancer Treat Rev 1981;8:93-102.

55. Olver IN, Roos IA, Thomas K, Hillcoat BL. Development of a murine gastric distension model for testing the emetic potential of new drugs and efficacy of antiemetics. Chem Biol Interact 1989;69:353-7.

56. Broomhead J, Fairlie D, Whitehouse MW. Cis-Platinum (II) amine complexes: some structure-activity relationships for immunosuppressive, nephrotoxic and gastrointestinal (side) effects in rats. Chem Biol Interact 1980;31:113-32.

57. Bearcroft CP, Domizio P, Mourad FH, Andre EA, Farthing MJ. Cisplatin impairs fluid and electrolyte absorption in rat small intestine: a role for 5-hydroxytryptamine. Gut 1999;44:174-9.

58. Riezzo G, Clemente C, Linsalata M, D'Attoma B, Orlando A Campanella G, et al. Gut peptide profile and chemotherapyassociated dyspepsia syndrome in patients with breast cancer undergoing FEC60 chemotherapy. Anticancer Res 2013;33:4951-7.

59. Phillips TD, Sarr AB, Grant PG. Selective chemisorption and detoxification of aflatoxins by phyllosilicate clay. Nat Toxins 1995;3:204-13.

60. Phillips TD. Dietary clay in the chemoprevention of aflatoxininduced disease. Toxicol Sci 1999;52 Suppl 1:118-26.

61. Beck I, Jenkins N, Thurber L, Ambrus JL. Methods for the study of antidiarrheal agents. Study of commonly used protective and adsorbent agents. J Med 1977;8:135-58. 